\title{
Model Simulations of Complex Dust Emissions over the Sahara during the West African Monsoon Onset
}

\author{
Carolina Cavazos-Guerra and Martin C. Todd \\ Department of Geography, University of Sussex, Chichester I Building, Falmer, Brighton BN1 9QJ, UK \\ Correspondence should be addressed to Carolina Cavazos-Guerra, c.cavazos-guerra@sussex.ac.uk
}

Received 30 November 2011; Revised 20 February 2012; Accepted 6 March 2012

Academic Editor: Pawan Gupta

Copyright ( 2012 C. Cavazos-Guerra and M. C. Todd. This is an open access article distributed under the Creative Commons Attribution License, which permits unrestricted use, distribution, and reproduction in any medium, provided the original work is properly cited.

\begin{abstract}
The existing limitations in ground-based observations in remote areas in West Africa determine the dependence on numerical models to represent the atmospheric mechanisms that contribute to dust outbreaks at different space-time scales. In this work, the ability of the Weather Research and Forecasting model coupled with the Chemistry (WRF-Chem) model using the GOCART dust scheme is evaluated. The period comprises the West African Monsoon onset phase (the 7th to 12th of June, 2006) coinciding with the AMMA Special Observing Period (SOP). Different features in the horizontal and vertical dynamical structure of the Saharan atmosphere are analyzed with a combination of satellite and ground-based observations and model experimentation at 10 and $30 \mathrm{~km}$ model resolution. The main features of key Saharan dust processes during summer are identifiable, and WRF-CHEM replicates these adequately. Observations and model analyses have shown that cold pools (haboobs) contributed a substantial proportion of total dust during the study period. The comparative analysis between observations and WRF-Chem simulations demonstrates the model efficiency to simulate the spatial and 3D structure of dust transport over the Sahara and Sahel. There is, therefore, a strong basis for accurate forecasting of dust events associated with synoptic scale events when model dust emission parameterization is suitably calibrated.
\end{abstract}

\section{Introduction}

Mineral dust is the dominant natural atmospheric aerosol by mass [2], and although the extent of its contribution is still uncertain, it plays an important role in the Earth climate system $[3,4]$. The Sahara Desert in North Africa is the world most important dust source with $\sim 50 \%$ of the total dust global mass [5]. Following field campaigns and new satellite data information, aerosol and climate scientists have increased our understanding of the Saharan dust cycle, particularly (i) preferential dust sources and especially those associated with topographic and geomorphological features including the Bodélé Depression $[6,7]$ the flanks of the Hoggar and Air mountains, amongst others [8], (ii) the complex meteorological processes leading to dust lifting in these sources (for a schematic of these mechanisms, refer to Cuesta et al., [9], Figure 1), (iii) the dynamical mechanisms controlling the structure of the Saharan atmosphere and the role of dust, and (iv) the radiative impact of dust aerosols.
Dust emissions over North Africa are closely coupled to the large-scale atmospheric circulation in the region and the pronounced seasonal and diurnal cycles [10-12]. In essence, the main seasonal climatic feature in North and West Africa is the annual cycle of dry and rainy monsoon seasons resulting from the north-south migration of the Intertropical Convergence Zone (ITCZ). The Intertropical Discontinuity (ITD) lies at the interface between the low-level moist southwesterly monsoon flow and the dry northeasterly "Harmattan" flow [13]. Harmattan winds are driven by the north-south pressure gradient across the zonal extension of the North African subtropical anticyclone (the Libyan high) and the monsoon trough, predominantly during winter months (OctoberMarch) over the entire Sahara-Sahel, as the ITD lies at $\sim 5^{\circ} \mathrm{N}$, close to the Gulf of Guinea coast.

Day-to-day synoptic scale variability in the Harmattan winds is associated primarily with variability in the mid-latitude circulation, especially ridging of the Libyan high [14], 


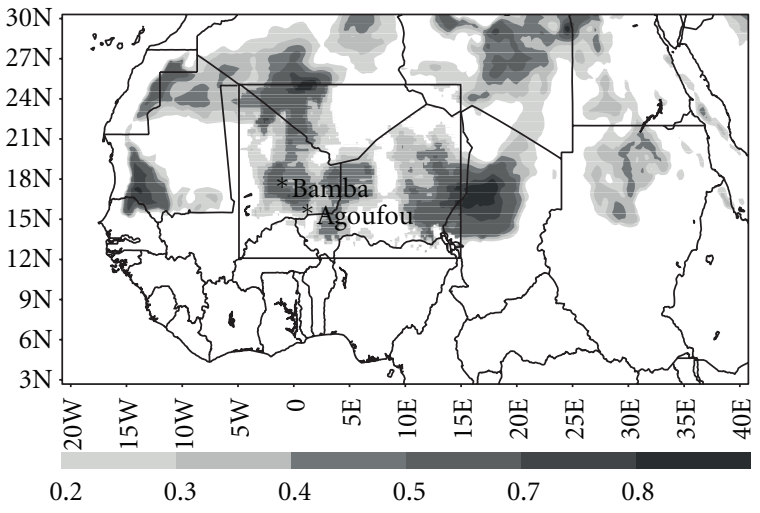

FIGURE 1: WRF-Chem model domain for $30 \mathrm{~km}$ horizontal grid EXP30 and for $10 \mathrm{~km}$ horizontal grid EXP10 (small square). Shaded area represents percentage of erodibility as dust source function for the GOCART scheme. Letters indicate locations of meteorological stations within EXP10 domain operational during AMMA IOP.

coastal "Sharav" cyclones [15], and cold surges [16]. Accordingly, during winter, dust events are generally associated with anomalously strong Harmattan wind events at the synoptic scale [17]. Within this, there is a pronounced diurnal cycle of dust emission, which peaks in the midmorning. This is associated with the diurnal cycle in low level and surface winds driven by surface heating and cooling through the inertial oscillation mechanism [18]. This results in an outof-phase coupling between nocturnal low-level jet maximum and midmorning surface wind maximum as momentum from the LLJ is mixed down to the surface by heating in the hours after sunrise $[17,19]$.

In boreal summer, the West African Monsoon (WAM) dominates the circulation over the Sahara-Sahel region [20] as the ITD lies at its northernmost location $\sim 15-20^{\circ} \mathrm{N}$, separating the relatively moist, cool monsoon southwesterlies and the hotter, dry northeasterlies. A key driver of the circulation over the western Sahara during the summer is the Saharan heat low (SHL), which in June is centred close to $0^{\circ} \mathrm{E}, 20^{\circ} \mathrm{N}$ where surface temperatures peak [21,22]. Data limitation in the central Sahara has restricted analysis of the SHL, but studies based on satellite observations and model experiments highlight a contribution of the SHL to the enhancement of meridional monsoon circulation $[9,23,24]$. In summer midtropospheric flow is dominated at $\sim 600 \mathrm{hPa}$ by the African Easterly Jet (AEJ), centred at $\sim 10^{\circ} \mathrm{N}$, driven to the first order by the surface temperature gradient between the cool equatorial Atlantic and the Sahara [25]. Instabilities in the AEJ lead to the formation of synoptic scale African Easterly Waves (AEWs) [26]. The AEWs typically form west of $20^{\circ} \mathrm{E}$, propagate westward, and play an important role in the organization and propagation of Mesoscale Convective Systems (MCSs) over the Sahel and occasionally the Sahara [27]. MCS activity can be organized along a squall line at leading edge of the upper level AEW [28]. Surface troughs embedded in the AEW are sometimes referred to as Sudano-Sahelian depressions (SSDs) and can propagate towards the northwest into the Sahara where they can become cut-off lows [29].
During the WAM onset in May-June an extended portion of the western Sahara and Sahel exhibit high dust loadings with a maximum approximately collated with the SHL extending over southern Algeria, northern Mali, and northeast Mauritania [11, 12]. It is now believed that this aerosol maximum is due to a variety of emission and transport processes. On the synoptic scale, surface troughs frequently within AEWs [30] create anomalously strong winds and often dust emission in both the dry northeasterly flow leading the trough [31] and the moist southwesterly flow behind (e.g., the monsoon surges documented by Flamant et al. [32] and Bou Karam et al. [33]). Once again, surface wind velocity is closely coupled to the diurnal cycle of the nocturnal LLJ in both the Harmattan and monsoon flow [23].

At the mesoscale, gravity currents within MCSs generated by subsidence of air cooled by evaporation in dry air $[34,35]$ can cause strong surface winds. These cool, moist outflows ("cold pools") from deep convective systems cause the characteristic dust fronts called Haboobs [36-39], which can propagate at speeds on the order of $10 \mathrm{~ms}^{-1}$ for more than 24 hours, over many hundreds of kilometers, sometimes far away from the parent convective clouds [40]. In addition, small-scale turbulence from dry convection [21] has been implicated in dust emission [12], although the importance of this mechanism has been a subject of debate [41]. Once dust is uplifted by these various mechanisms during summer, it is quickly mixed vertically by dry convection throughout the depth of the planetary boundary layer, which can exceed $5 \mathrm{~km}$ over the central Sahara, and by upgliding over the more dense monsoon flow [42]. Subsequently, dust is typically advected westward over the Atlantic within the elevated Saharan Air Layer (SAL) [43].

Model representation of the complex features affecting the dynamics of atmospheric circulation, which determine dust mobilization, is still a matter of intensive study. Adequate model simulation requires that models represent the large-scale, synoptic and mesoscale features of the Saharan atmosphere. Based on these premises, the ability of the Weather Research and Forecasting (WRF) model with a Chemistry module (WRF-Chem) to represent these key multiscale processes associated with dust mobilisation in the Sahara during the WAM onset is evaluated. The analyzed period (7th-12th of June 2006) corresponds to a period which encompasses the complexity of processes that operate during summer. This work is organized as follows. Section 2 describes model configuration and employed data for validation. Section 3 provides the results of model experiments including synoptic scale conditions and dust emissions and transport associated to the atmospheric mechanisms described previously. Section 4 summarizes the findings made in this work and conclusions.

\section{Methodology}

2.1. WRF-Chem Model Description. WRF is a next-generation mesoscale forecast model and assimilation system to advance both the understanding and prediction of weather. WRF is applied in a variety of research and operational contexts, from storm scale to regional climate scale [44]. 
The WRF-Chem incorporates a chemistry module that simultaneously simulates the emission, turbulent mixing, transport and chemical transformation, of trace gases and aerosols [45]. In this work, WRF-Chem implements the Goddard Global Ozone Chemistry Aerosol Radiation and Transport (GOCART) dust scheme, which includes emission, advection, and deposition and is fully described in Ginoux et al. [46]. In essence, the GOCART dust scheme simulates dust emission as a function of surface wind speed and surface erodibility and surface wetness [47]. Emission flux $F p$ for aerosol particle size group $p$ is expressed as

$$
F p=C S s p u_{10 \mathrm{~m}}^{2}\left(u_{10 \mathrm{~m}}-u_{t}\right) \text { if } u_{10 \mathrm{~m}}>u_{t},
$$

where $C$ is a dimensional, scheme-specific constant of proportionality equal to $1 \mathrm{mg} \mathrm{s}^{2} \mathrm{~m}^{-5}$ and $S$ is the erodibility source function, both values originally prescribed as in Ginoux et al. [46]. sp is the fraction of each size class within the soil, $u_{10 \mathrm{~m}}$ is the wind speed at $10 \mathrm{~m}$, and $u_{t}$ is the threshold velocity of wind erosion, determined by particle size and surface wetness. Due to the uncertainties in the available soil texture data, a simple particle size distribution following Tegen and Fung [48] is implemented. The fraction of clay is based on the assumption that erodible clay represents $1 / 10$ of the total mass of emitted silt and that of each silt subclass is assumed to be the same. The $s p$ values are thus 0.1 for the class $0.1-1 \mathrm{~mm}$ and 0.3 for the classes $1-1.8 \mathrm{~mm}, 1.8-3 \mathrm{~mm}$, and $3-6 \mathrm{~mm}$, respectively. The source function $S$ is defined from an erodibility map representing the fractional grid cell area of alluvium available for wind erosion as follows:

$$
S=\left(\frac{z_{\max }-z i}{z_{\max }-z_{\min }}\right)^{5},
$$

where $S$ is the probability of accumulated sediments in the grid cell $i$ of altitude $z i$ and $z_{\max }$ and $z_{\min }$ are the maximum and minimum elevations in the surrounding $10 \times 10$ topography, respectively. Only land surface with bare soil is considered as possible dust sources. The bare soil surface map is obtained from the $1 \times 1$ vegetation data set derived from the Advanced Very High-Resolution-Radiometer (AVHRR) data [49]. In general, source regions are characterized as erodible fraction areas higher than 30\% particularly with an elevated proportion of sand. For this research, a new version from this erodible fractional map derived from AVHRR at a higher resolution $0.25^{\circ} \times 0.25^{\circ}$ is used (Figure 1). This new map provides a more detailed representation of the source regions within the Bodélé Depression, Chad, and identifies smaller local dust sources elsewhere. Like most dust emission schemes in models it is necessary to "tune" emission to account for many unconstrained parameters the magnitude of some depending on model horizontal resolution. As described above, constant $C$ in (1) is an empirical proportionality constant that was originally estimated based on regional datasets. In this analysis, we tuned this constant $C$ as in Zhao et al. [50]. These authors tuned $C$ values of 0.65 in contrast to the $1 \mathrm{mg} \mathrm{s}^{2} \mathrm{~m}^{-5}$ from Ginoux et al. [46] to replicate consistence with AERONET datasets. Following a similar approach, we did fix this to value $0.5 \mathrm{mg} \mathrm{s}^{2} \mathrm{~m}^{-5}$ to produce consistency between model
TABLE 1: Model configuration used for experimentation.

\begin{tabular}{ll}
\hline Model name & WRF-Chem \\
\hline Reference & Grell et al. [45] \\
Boundary conditions & NCEP Final Analysis FNL (1.125 deg) \\
& $5^{\circ}-30^{\circ} \mathrm{N}, 20^{\circ} \mathrm{W}-40^{\circ} \mathrm{E}$ and $8^{\circ} \mathrm{N}-29^{\circ} \mathrm{N}$, \\
& $12^{\circ} \mathrm{W}-22^{\circ} \mathrm{E}$
\end{tabular}

simulated and with satellite observational aerosol optical thickness (AOT) retrievals from MODIS Deep Blue satellite data (see Sections 2 and 3) for the period under analysis.

2.2. Model Configuration. The various model domain configurations and physics options are summarised in Table 1. Model configurations selected are based on previous sensitivity experimentation of the different available cumulus, PBL and microphysics parameterization by the authors not included in this work and the findings of several sensitivity analyses documented by the modeling community (e.g., [5153]). The cumulus parameterization scheme employed is the G-3D, which is an improved version of the Grell-Devenyi (GD) ensemble cumulus scheme [54]. The GD scheme has been recommended for smaller model grid scales (e.g., 10$30 \mathrm{~km}$ ) as it tends to allow a balance between the resolved scale rainfall and the convective rainfall. Multiple cumulus ensembles are averaged within each grid box in an attempt to represent different cloud processes, such as detrainment and precipitation as well as explicit representation of updraughts and downdraughts. The G-3D version also allows for subsidence in neighboring columns. Sensitivity experiments in the WRF using the GD scheme have shown a good performance to detect convection development [55]. The Planetary Boundary Layer (PBL) scheme utilized is the Mellor-Yamada-Janjic TKE scheme as it has proved to represent more realistically in terms of temperature and humidity and PBL height [53].

To test the sensitivity to model horizontal resolution two WRF-CHEM experiments are performed, with model grid sizes of 30 and $10 \mathrm{~km}$, EXP30 and EXP10, respectively. In the vertical plane the model has 50 vertical levels heavily biased towards the boundary layer (22 layers in the bottom 
$1 \mathrm{~km}$ ). The two model domains encompass $5^{\circ}$ to $30^{\circ} \mathrm{N}-20^{\circ} \mathrm{W}$ to $40^{\circ} \mathrm{E}$ and $8^{\circ} \mathrm{N}-29^{\circ} \mathrm{N}, 12^{\circ} \mathrm{W}-22^{\circ} \mathrm{E}$ for the $30 \mathrm{~km}$ and $10 \mathrm{~km}$ grid resolutions experiments, respectively. The period considered in this study is part of the Special Operation Period Phase 1 (SOP1, 2006) of the African Monsoon Multidisciplinary Analysis (AMMA) during the monsoon onset (May-June). This campaign consisted of a multiscale and multiprocess analysis of the west African monsoon [56]. Refer to Redelsperger et al. [57] for a comprehensive description of the AMMA field campaign. The initial boundary conditions are generated from NCEP Final Analysis (FNL from GFS) $1 \times 1$ degree resolution, every 6 hours. Model simulation EXP30 is performed from 5th to 15th June 2006, whilst EXP10 focuses on a shorter period from 7 th to 10th of June, when mesoscale convection was particularly active over the southern Sahara.

2.3. Observational Datasets. The spatial distribution of modelled dust is compared with a comprehensive set of satellite datasets providing information on atmospheric dust aerosols. These consist of (i) the EUMETSAT dust product color-composite from the SEVIRI sensor available at a 15minute temporal and $5 \mathrm{~km}$ nadir spatial resolution; the dust Product is generated from the SEVIRI Brightness Temperatures in three channels located in the infrared (8.7, 10.8 , and $12.0 \mu \mathrm{m}$ ) [58] and is a qualitative dataset proven useful to identify active dust sources (e.g., [8]); (ii) AOT from MODIS-Aqua Collection 5.1 Level 2 (10 km spatial resolution, daily at local noon) using the latest version of the Deep Blue algorithm [1], providing AOT even over highly reflective desert surfaces; (iii) several transects from the CALIOP Lidar Version 3 Level 2 extinction coefficient at $532 \mathrm{~nm}$ and the Vertical Feature Mask data product (VFM) with $30 \mathrm{~m}$ vertical resolution that are used to evaluate dust vertical structure $[59,60]$. Although the L2 extinction coefficient retrieval from CALIOP is still a beta-quality product, it is useful to evaluate model dust profile structure in combination with a more validated VFM product. Meteorological data within Sahara itself is sparse and we use observations enhanced by the AMMA project from within the domain of EXP10, specifically surface SYNOPS reports from Agoufou and Bamba (Figure 1).

\section{Results and Discussions}

3.1. Synoptic Scale Conditions the 7th to the 12th of June, 2006. The meteorological situation during the period under analysis has been partly described in Flamant et al. [64]. These authors focused their analysis on dust emission and transport from the Bodélé Depression and Sudan regions from the 9th to the 14th of June, 2006. In the present research, analysis is extended to include the whole extent of the Sahara-Sahel. The large-scale circulation simulated by WRF (Figure 2) at 06 UTC each day (the approximate time of maximum nocturnal low-level monsoon winds [23]) is consistent with reanalysis data (not shown) and shows a number of key features: (i) a positive sea level pressure (SLP) anomaly over the central/eastern Mediterranean and Libyan sector driving enhanced northeasterly Harmattan winds over the eastern sector of the Sahara (Chad-Sudan); although this SLP anomaly declines gradually over the period, northeasterly Harmattan winds are strong throughout; (ii) a series of westward propagating tropical troughs characteristic of SSD events (features SSD1 and SSD2 in Figure 2), which curve northwestward as they approach the western extremity of the Sahara. The propagation of the SSD troughs is highlighted in the SLP time-longitude analysis (Figure 3 ) at $15^{\circ} \mathrm{N}$ and suggests a displacement speed of about $880 \mathrm{~km}^{\text {day }}{ }^{-1}$ consistent with AEW activity at $15^{\circ} \mathrm{N}$ in the study of Kiladis et al. [65]. Figure 2 highlights pronounced meridional ITD perturbations associated with the passage of SSD troughs. Moist (dry) air is advected northward (southward) within the southwesterly (northeasterly) flow behind (ahead of) the center of the SSD trough. For example, monsoon "surges" extend as far north as $\sim 21^{\circ} \mathrm{N}$ at $\sim 0-5^{\circ} \mathrm{E}$ on the 7 th- 8 th of June, associated with SSD1 (Figure 2(b)) and $20^{\circ} \mathrm{E}$ on the 8th-9th of June, associated with Feature SSD2 (Figure 2(d)), and play an important role in preconditioning moist convection over the Sahara as described in later sections.

3.2. Mesoscale Moist Convection. Large-scale organized convection was active over the Sahel south of $\sim 15^{\circ} \mathrm{N}$ throughout the study period. Of particular interest were MCS events further north than normal (Figure 4) within the monsoon surges around the SSD troughs, specifically, (i) deep convection on the nights of the $8 / 9$ th of June at $\sim 0^{\circ} \mathrm{E}$ over Mali/Algeria (Feature DC1 in Figure 4(c)) and (ii) on the evening and night of the 9/10th of June over the Hoggar mountains of Algeria (Feature DC2 in Figure 4(e)) and further east at $\sim 15-20^{\circ} \mathrm{E}$ over Niger/Chad on the early morning of the 10th of June (Feature DC3 in Figure 4(e)). These MCS events produced pronounced cold pool outflow winds, evident from satellite as "haboob" dust emission events (Features H1, H2, and H3, resp., in Figure 4).

3.3. Dust Emission and Transport Model Simulations and Observational Data. The following sections describe the synoptic and mesoscale low-level wind features combined to drive a complex set of dust emission events over the Sahara during the study period. Dust source regions and plume transport can be most unambiguously identified from the high-temporal-resolution SEVIRI imagery (Figure 4).

Quantitative estimates of AOT from MODIS are shown in Figure 5 whereas WRF-CHEM EXP30 AOT estimates for comparison are shown in Figure 6. The contribution of processes identified for dust emissions and transport in the model and from observations over the study period is analysed below.

\subsubsection{Dust Emission Associated with Enhanced Harmattan} Northeasterlies. Dust emission is apparent from a number of source regions in Sudan and Chad in the pink product derived from SEVIRI imagery, including the Bodélé Depression every day from the 8 th to the 11 th of June (Figure 4 features B1 to B4, also apparent as high AOT values in Figures 5 and 6 from MODIS and model estimations). Over the Bodélé dust emission appears most active on the 9th of June (Figure 6). The same day peak wind speeds at $10 \mathrm{~m}$ height 


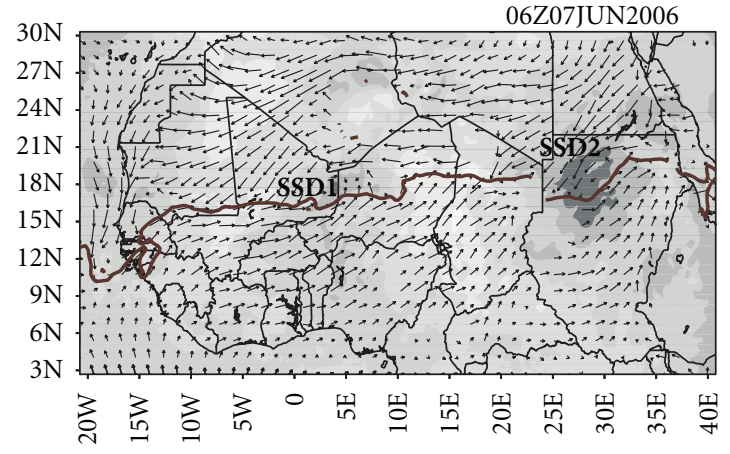

(a)

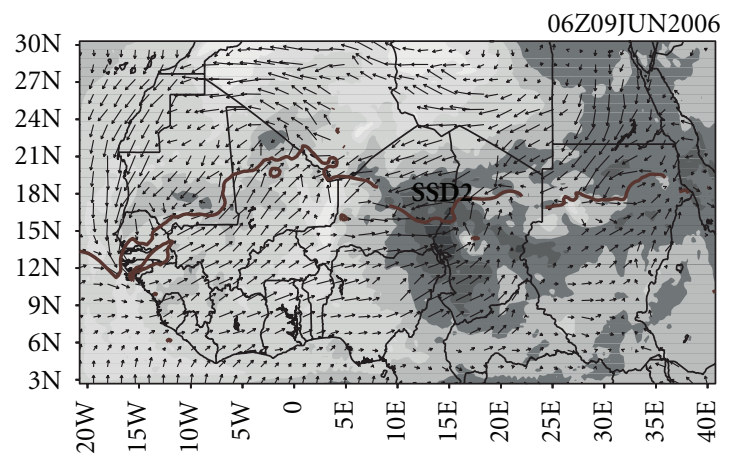

(c)

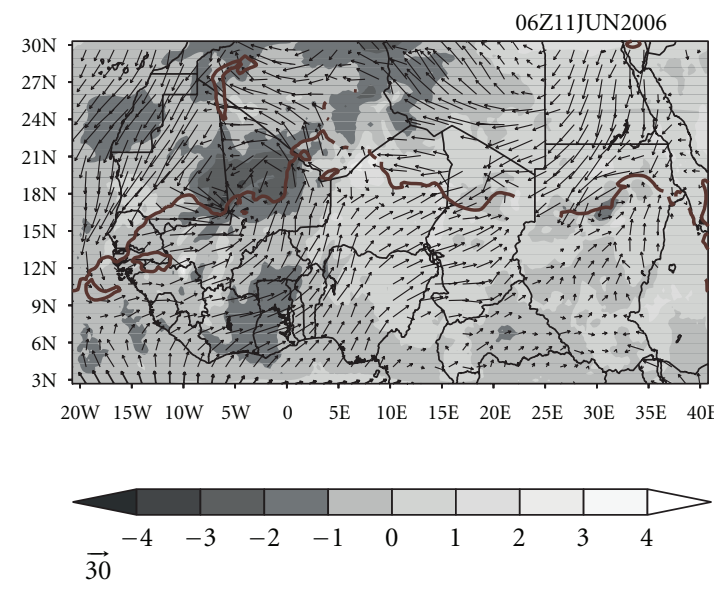

(e)

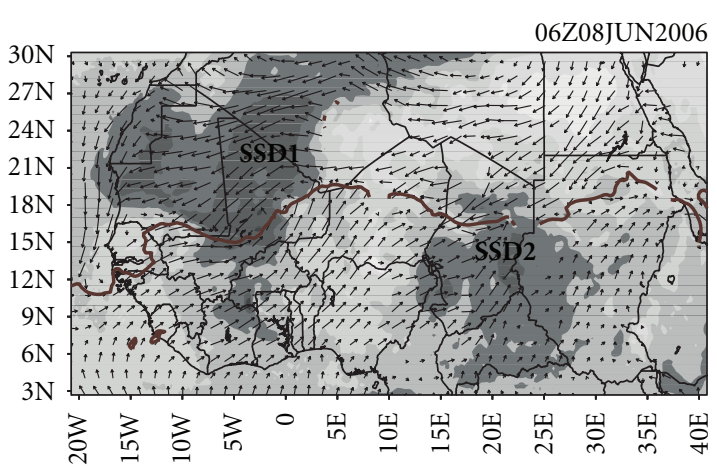

(b)

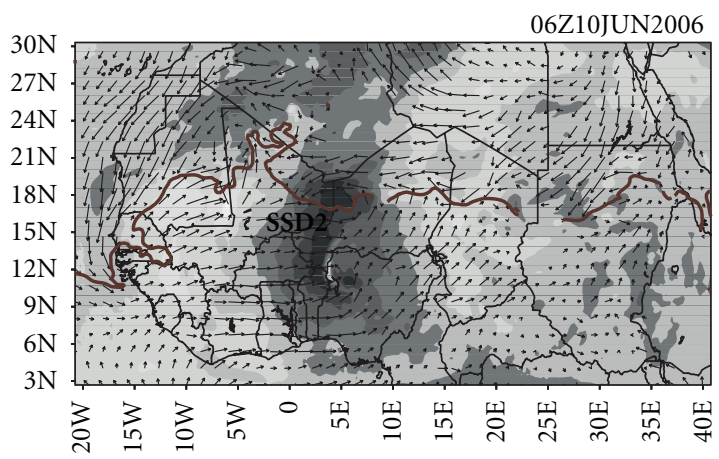

(d)

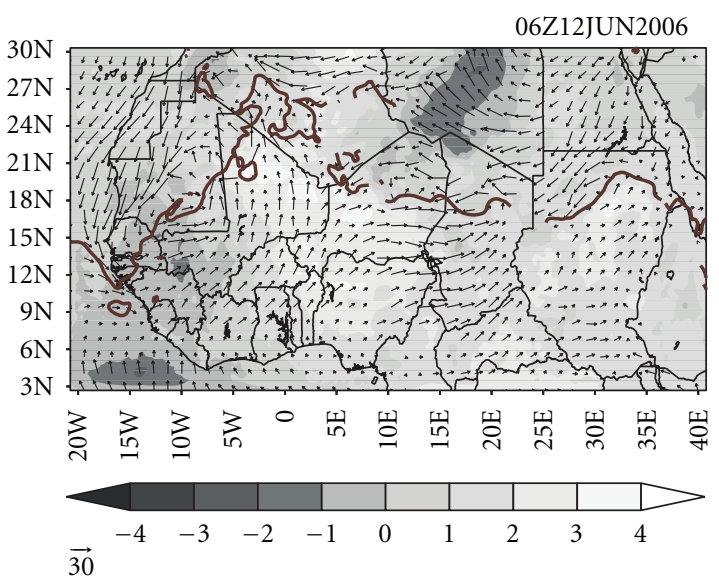

(f)

FIGURE 2: Synoptic weather conditions during the study period. WRF-Chem EXP30-simulated sea level pressure (shaded) at 0600 UTC with the diurnal cycle removed, winds at $925 \mathrm{hPa}$ (vectors), brown line indicates the $12 \mathrm{gr} \mathrm{kg}$ water vapor isopleth (approximate ITD location). (a) 7th, (b) 8th, (c) 9th, (d) 10th, (e) 11th, and (f) 12th of June, 2006.

exceed the $18 \mathrm{~m} \mathrm{~s}^{-1}$ as the synoptic scale flow is channeled between the Tibesti and the Ennedi. Dust emission shows the diurnal cycle with the characteristic late morning peak in dust activity, which has been documented by Washington et al. [6] and Todd et al. [19]. This is the result from the out-of-phase relationship of LLJ, and surface wind speed is well represented by WRF-CHEM EXP30 (Figure 8). The dayto-day variability in wind speeds over the Bodélé matches that in approximate dust plume magnitude with peak winds and plume size on the 9th of June (Figure 6(a)) when $10 \mathrm{~m}$ wind speeds in excess of $14 \mathrm{~m} / \mathrm{s}$ are simulated (Figure 8(a)).
High wind speeds are maintained the following two days (the 10th and 11th of June). This coincides with high dust emissions from this region as shown in the SEVIRI images (Figure 4 features B1 and B2). WRF-Chem EXP30 represents both the Bodélé plumes well (Figure 6) including day-to-day variability and the diurnal cycle evident from SEVIRI. Mean emissions in EXP30 exceed $1.1 \times 10^{-3} \mathrm{~g} \mathrm{~m}^{-2} \mathrm{~s}^{-1}$, whereas dust concentrations over the Bodélé from the WRF-Chem exceed $10000 \mu \mathrm{m} \mathrm{m}^{-3}$. A day-to-day evaluation between model AOT and satellite AOT reflects very strong correspondence of these datasets during this critical period for dust emissions 


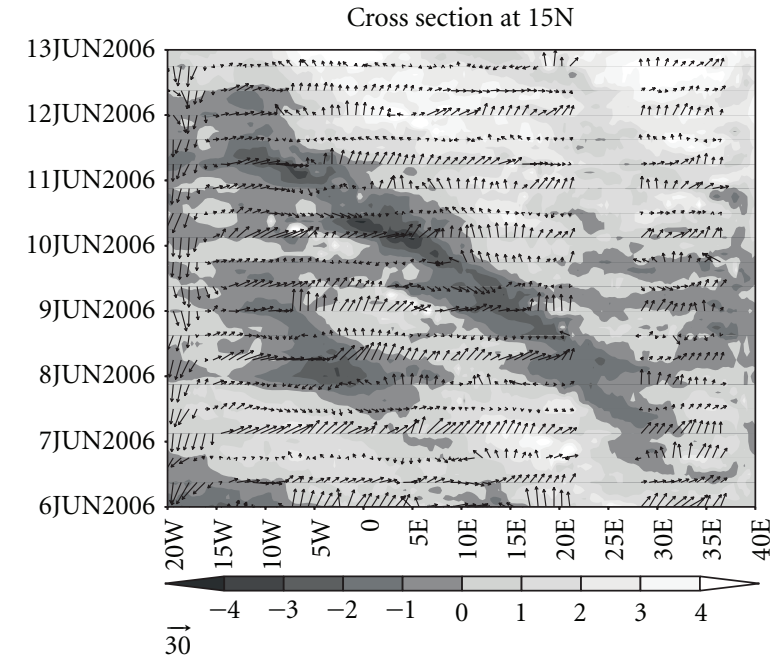

FIgURE 3: Time-longitude diagram of WRF-Chem EXP30simulated sea level pressure with the diurnal cycle removed at $15^{\circ} \mathrm{N}$.

(Figure 7). Average AOT values daily during the peak days of dust emissions (9th and 10th of June) are $\sim 0.91$ for the MODIS observations and 0.80 for model AOT following a normal distribution in both cases as shown in PDFs in the same (Figure 7). To the west, in southern Algeria weaker dust emission is evident on the 7th and 8th of June (Features A1 and A2 in Figure 4) where a topographic influence is apparent. Discrete dust plumes emerge during the morning from the lacustrine deposits west of the town of In Salah driven by high wind speeds up to $12 \mathrm{~m} \mathrm{~s}^{-1}$, accelerated around the northern flank of the Hoggar mountains. These dust plumes are well represented in WRF-CHEM (Figure 6), and the model indicates a diurnal cycle of LLJ and surface winds similar to but weaker than that over the Bodélé (Figure 10(b)), which drive the characteristic diurnal cycle in dust emission creating plumes A1 and A2.

Other active dust source areas influenced by low-level northeasterly winds are located in North Sudan (over an area approximately bounded by $15-20^{\circ} \mathrm{N}, 20-25^{\circ} \mathrm{E}$ ). The Sudanese sources have been reported to be particularly active in May-July by several authors $[64,66]$. Clear examples are regions near the Nubia Desert in northern Sudan where the topography is mainly characterized with dense drainage channels like wadis likely to provide fluvial sediments. A particularly active source is located especially close to $16^{\circ} \mathrm{N}$, $25^{\circ} \mathrm{E}$. Generally, WRF-Chem captures these features reasonably well although it produces a rather generalized emission without representation of the major localized sources. Overall, WRF-CHEM captures well the space/time distribution of dust plumes from a number of preferential source regions in the Sahara, activated by synoptic scale winds constrained by topographic influences, although the fine detail of plume source location is lost in some cases.

3.3.2. Dust Emission Associated with Cold Pool Features (Haboobs). The most prominent "haboob" events are observed in SEVIRI imagery and are labelled $\mathrm{H} 1-\mathrm{H} 3$ in Figure 4.
Time development of $\mathrm{H} 1$ case can also be followed in Figure 9. Note that the "haboob" dust front may only activate emission for a short period of perhaps a few hours. Subsequently, the dust plume is transported and modified. The major events are (i) over northern Mali/southern Algeria on the 8th/9th of June (Feature H1 in Figures 4(c)-4(d)), (ii) over central-southern Algeria on the 10th of June (Feature $\mathrm{H} 2$ in Figure 4(f)), and (iii) over eastern Niger on the 9th/10th of June (Feature H3 in Figure 4(f)). In the case of (i) extensive deep convective systems (Feature DC1 in Figure 4(c)) developed in a SW-NE oriented squall line extending across Niger in the evening of the 8th of June, propagating westward towards the Mali/Niger border on the night of the 8th-9th of June, within the monsoon extension around the eastern flank of SSD1 (Figure 2(b)). These convective cells generated cold pool outflows evident from the associated dramatic haboob dust front extending at least $1000 \mathrm{~km}$ in length from central eastern Mali to the Hoggar uplands of southern Algeria at 00 UTC on the 9th of June. This dust front propagated towards the NW to result in a dust plume extending from central Mali to southern Algeria by 12 UTC on the 9th of June, and then transported north to central-western Algeria on the 10th of June, in the northward intrusion of the monsoon flow. This extensive dust emission is not accurately simulated by WRF-Chem EXP30 at $30 \mathrm{~km}$ resolution (Figure 6(c)). Although a weak dust plume oriented SW-NE across Mali-Algeria is evident, the emission occurred in the midmorning hours of the 9th of June associated with mixing of the nocturnal monsoon LLJ to the surface after sunrise, reminiscent of the mechanism identified by Bou Karam et al. [33]. In contrast, the model simulation EXP10 at $10 \mathrm{~km}$ resolution resolves well the timing and extent of convective systems within the monsoon surge and, crucially, the associated westward propagating cold pool outflows (Figure 12). In the model wind speeds at $10 \mathrm{~m}$ height in excess of $18 \mathrm{~m} \mathrm{~s}^{-1}$ are simulated along these moist gust fronts over western Niger and eastern Mali over the period $18 \mathrm{UTC}$ on the 8 th to $06 \mathrm{z}$ on the 9th of June (Figure 9), which generate dust emission subsequently transported towards the northwest with elevated AOT values. These simulated gust/dust front features map well in terms of timing and location with the observed dust front (Feature $\mathrm{H} 1$ in Figure 4). Unfortunately, it is not possible to verify quantitatively the model AOT with MODIS AOT product set due to low data quality caused by cloud screening in this particular area during this period.

The time series of $10 \mathrm{~m}$ wind speed (Figure 10) in EXP10 compare well with the observed wind speeds at stations Bamba and Agoufou. The timing of the passage of the cold pool events on the early hours of the 9th of June is coincident with observations although the magnitude of peak winds is underestimated. The timing and magnitude of peak wind speeds are far better resolved in the $10 \mathrm{~km}$ model run EXP10 than in the $30 \mathrm{~km}$ run EXP30.

During the night of the 9th and daytime of the 10th of June further deep convection occurs over central southern Algeria (Feature DC2 in Figure 4(e)). Associated haboob events are evident over central-western Algeria (H2) and augment the existing dust plume. Moist convective processes 


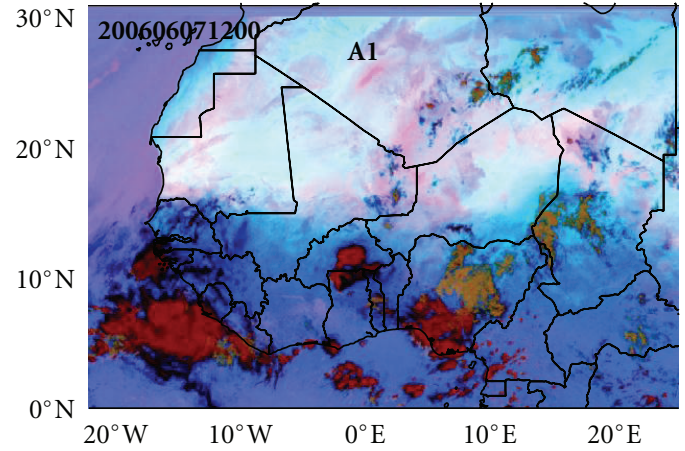

(a)

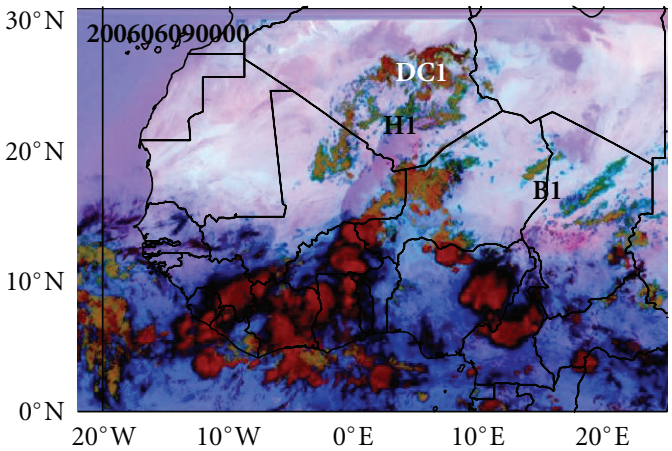

(c)

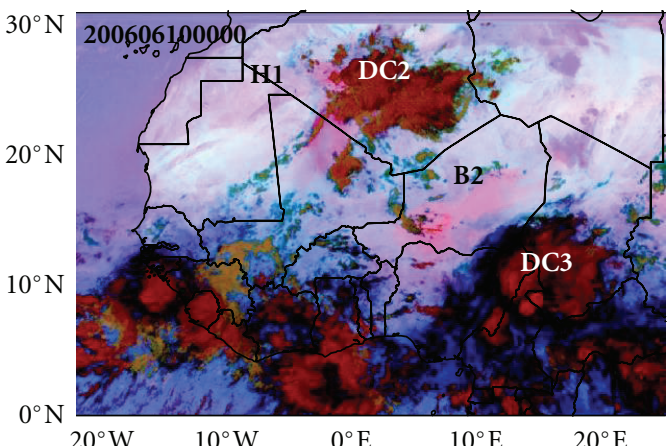

(e)

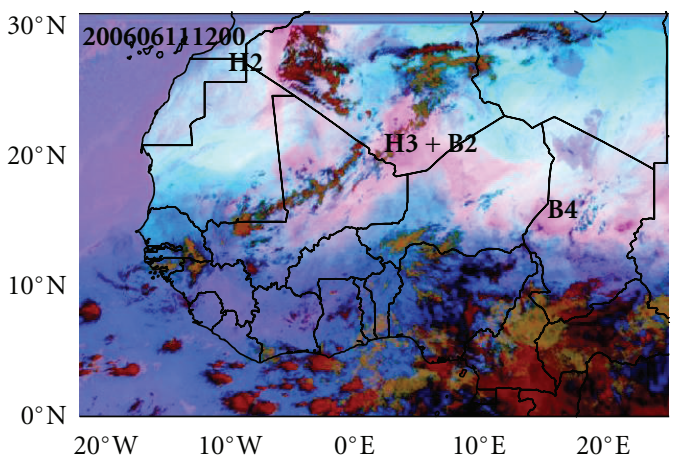

(g)

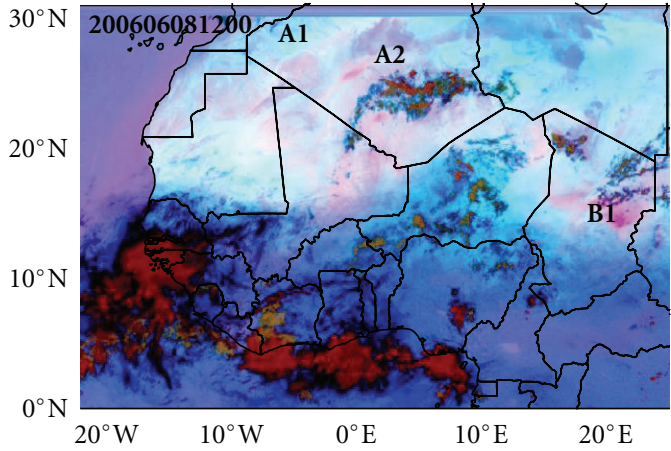

(b)

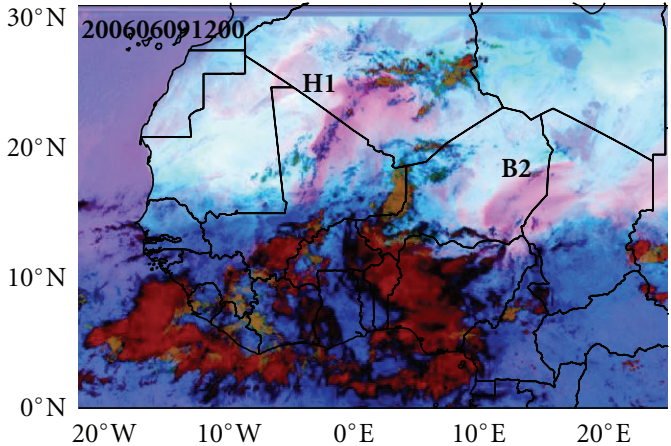

(d)

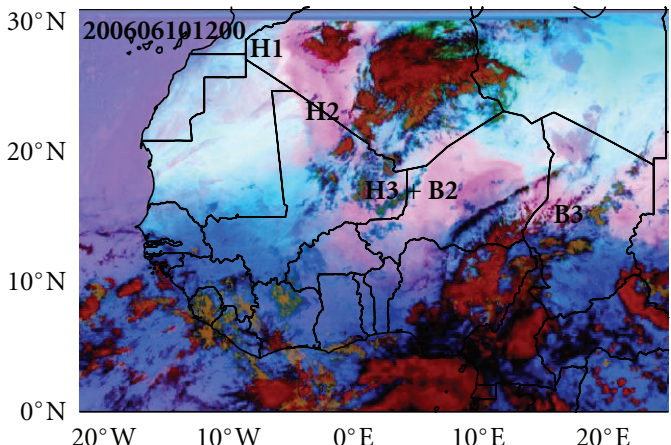

(f)

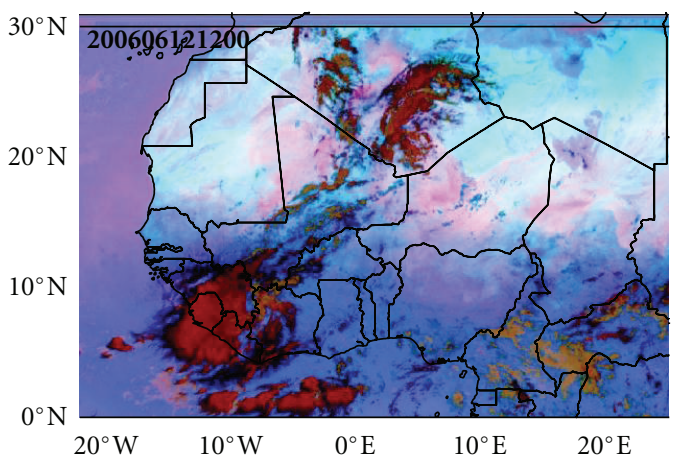

(h)

FIGURE 4: SEVIRI false color dust product imagery at 1200 UTC each day over the study period. Pink tones indicate dust and red-brownblack tones indicate clouds. Letters correspond to major dust and cloud features of interest (see text for details). 


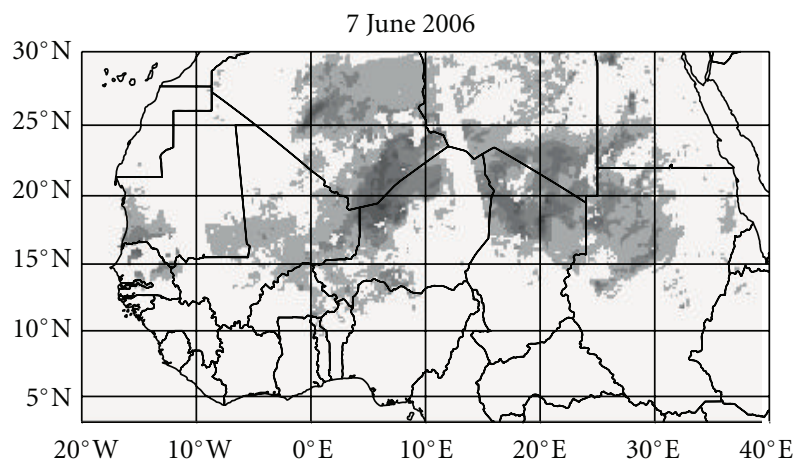

(a)

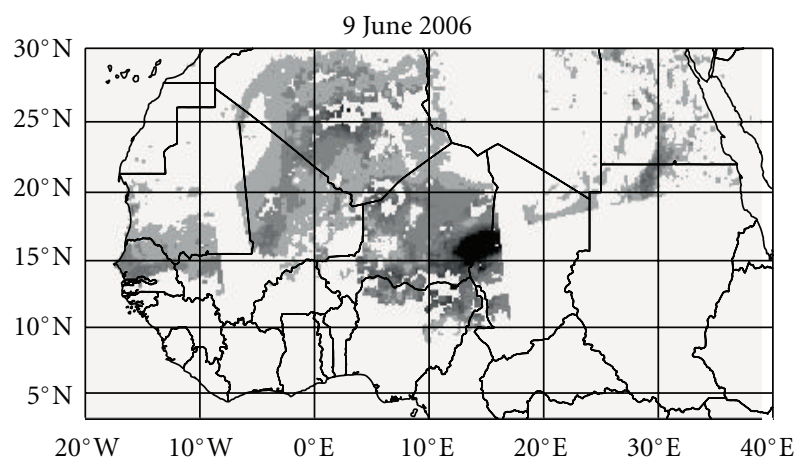

(c)
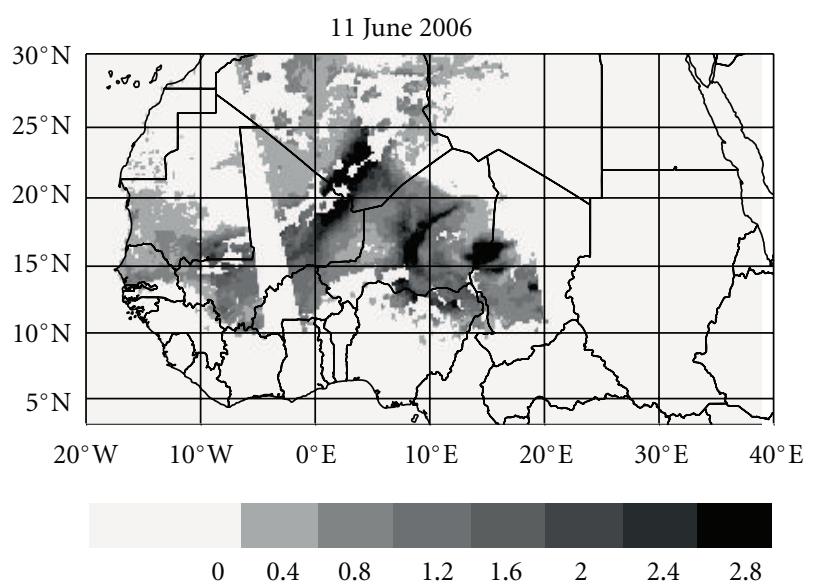

(e)

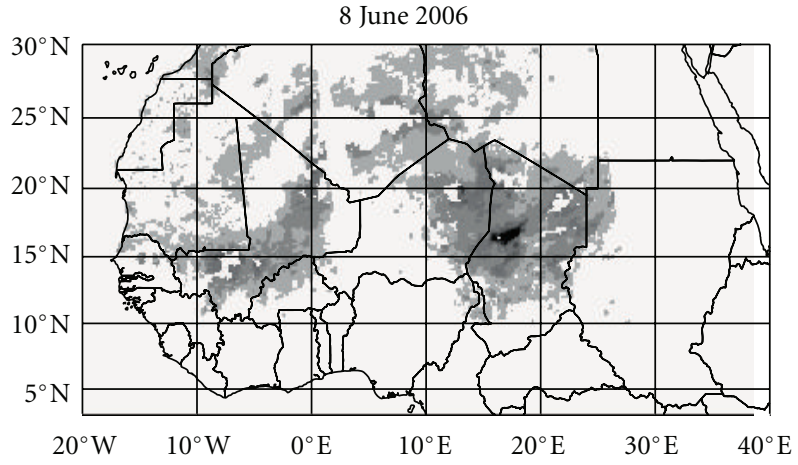

(b)

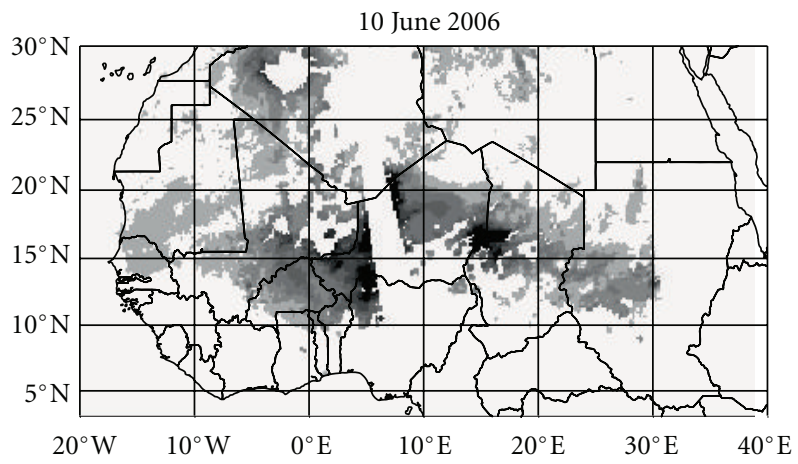

(d)

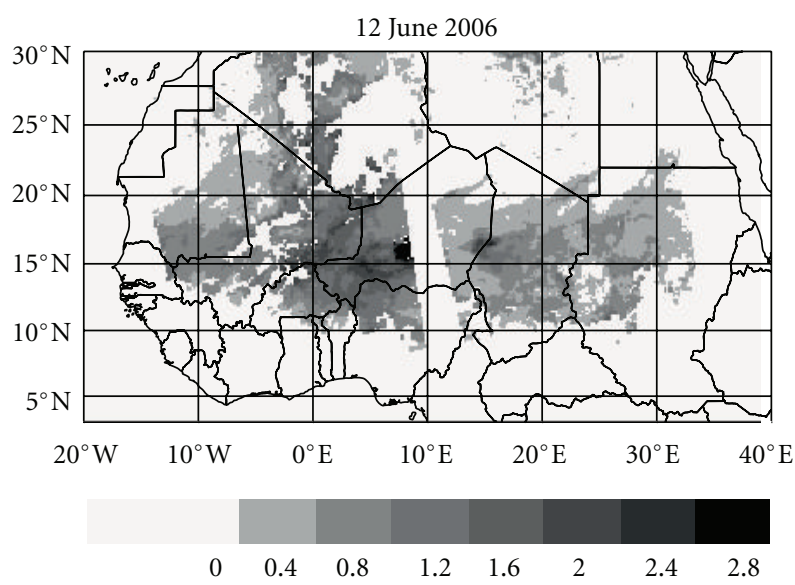

(f)

Figure 5: MODIS AOT estimates from the "Deep Blue" product [1] over north and west Africa from the 7th to 12 th of June, 2006 at around 13.30 local time.

this far into the central Sahara are rather anomalous and may have been triggered by the intrusion of the moist dusty cold pool air mass propagating away from convection over eastern Mali/western Niger on the 8-9th of June described above and the upward vertical motion at the leading edge of the haboob. In that way haboob events can provide the preconditions favouring further convection and haboobs [67]. The role of dust in the thermodynamic and microphysical processes of convection can only be speculated in this study, in the absence of observational data. The time average emissions in the region around the $25-27^{\circ} \mathrm{N}$ and $0^{\circ} \mathrm{E}$ at the southwest flanks of the Plateau of Tademait in Algeria indicate high emissions during the period under study. The magnitude of emissions in the WRF-Chem exceeds values around $60 \mathrm{~g} \mathrm{~m}^{-2} \mathrm{~d}^{-1}$ for the whole period.

During the 10th and 11th of June, 2006 further dust emission and transport occurs resulting in a vast plume in the form of an inverted " $\mathrm{V}$ " extending across Mali to southern Algeria and SE over Niger by 1200 UTC on the 11th of June (Feature H3 + B2 in Figure 4(g)). Analysis of plume evolution from SEVIRI indicates multiple sources and processes. First, dust emitted from the Bodélé Depression in 


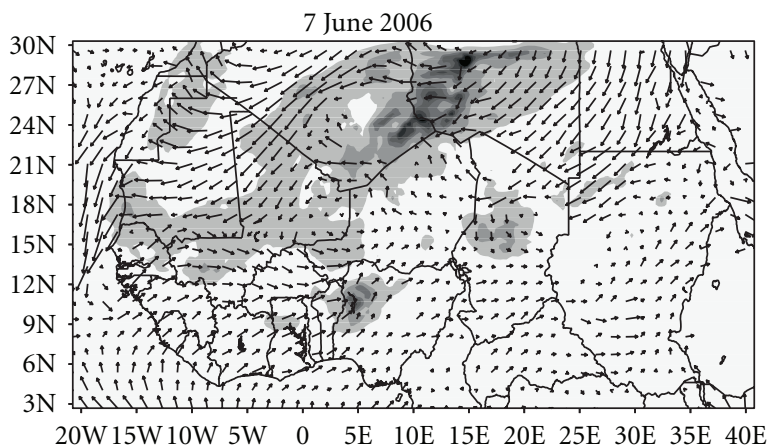

(a)

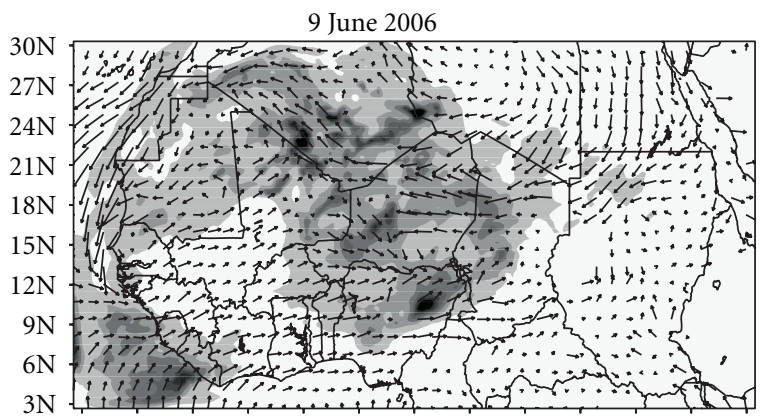

20W15W 10W 5W 0 5E $10 \mathrm{E}$ 15E 20E 25E 30E $35 \mathrm{E}$ 40E

(c)

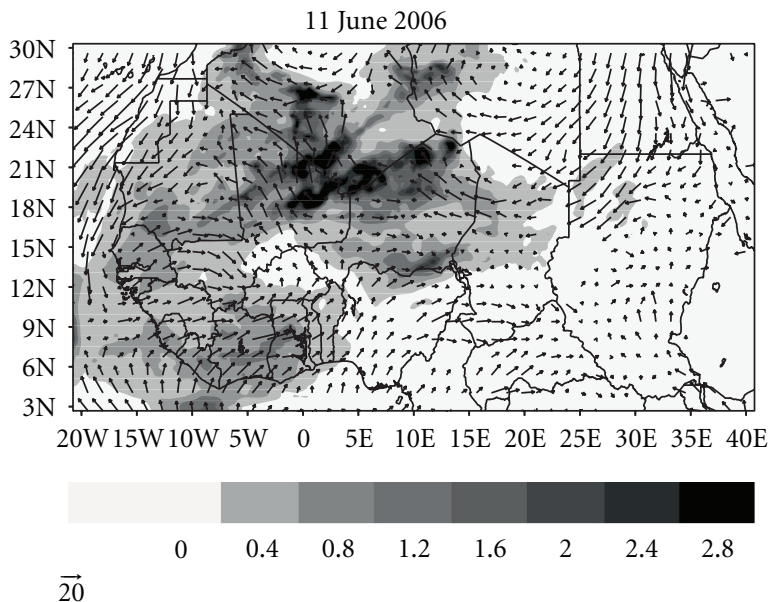

(e)

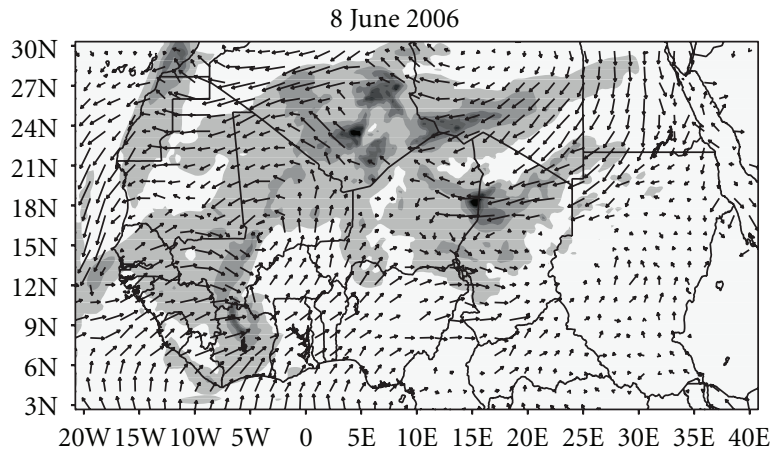

(b)

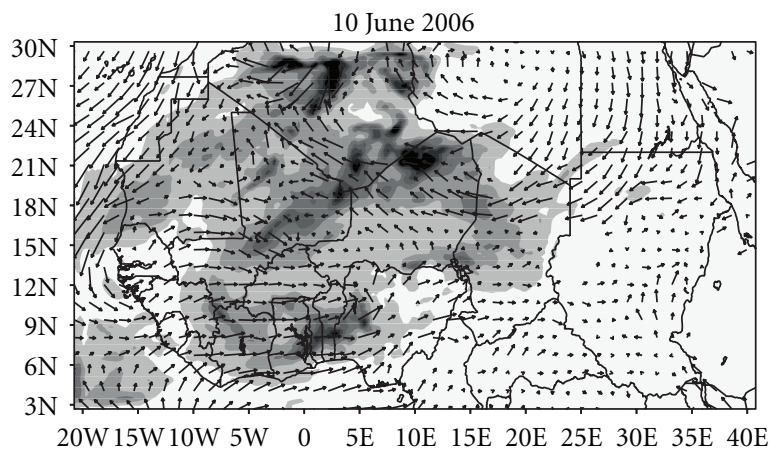

(d)

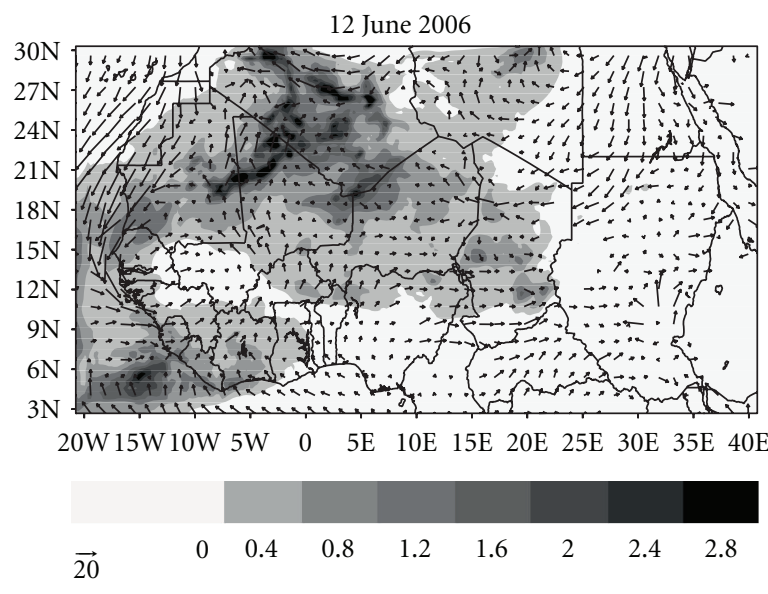

(f)

FIgURE 6: WRF-Chem EXP30-simulated AOT from the 7th to 12th of June, 2006 at 1200 UTC. Wind direction (vectors) at 925 mb is also shown.

the Harmattan flow on the 8th of June lays over eastern Niger by 1200 UTC on the 9th of June (Feature B2, Figure $4(\mathrm{~d})$ ). On the 10th of June the cold pool outflow from MCS system DC3 (Figure 4(f)) is evident from SEVIRI data as it both generates dust and advects northward the existing dust plume B2 over Niger. The resulting "hybrid" plume constitutes the eastern axis of the inverted "V" shape, lying over western Niger/southern Algeria on the 10th-11th of June. This was probably augmented by further emission over centraleastern Mali on the 11th of June associated with further scattered convective systems, constituting the western axis of the inverted "V", although cloud cover renders interpretation of emission sources and processes problematic. It appears that the inverted "V-" shaped plume at 1200 UTC on the 11th of June (Feature H3 + B2, Figure 4(g)) effectively extends around the boundary of the dry Saharan air and the moist monsoon flow intrusion (centred on the triple point of Algeria-Niger-Mali) as evidenced by the position of the ITD (Figure 2). The inverted "V" structure on the 11th of June is apparent from MODIS in the peak AOT values, although elevated AOT values extend south of the ITD suggesting underrepresentation of aerosol by SEVIRI in this 
9 June 2006

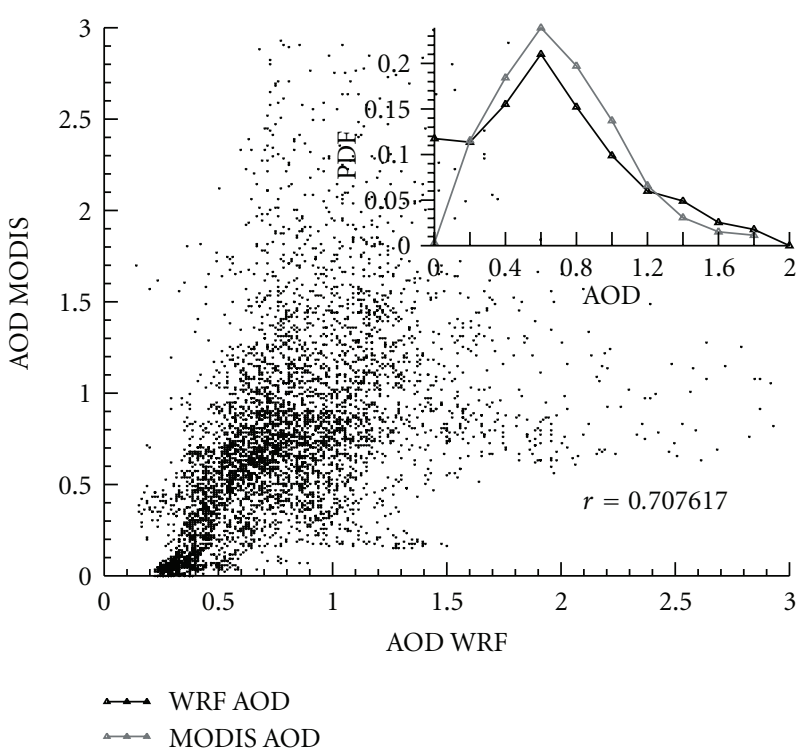

(a)

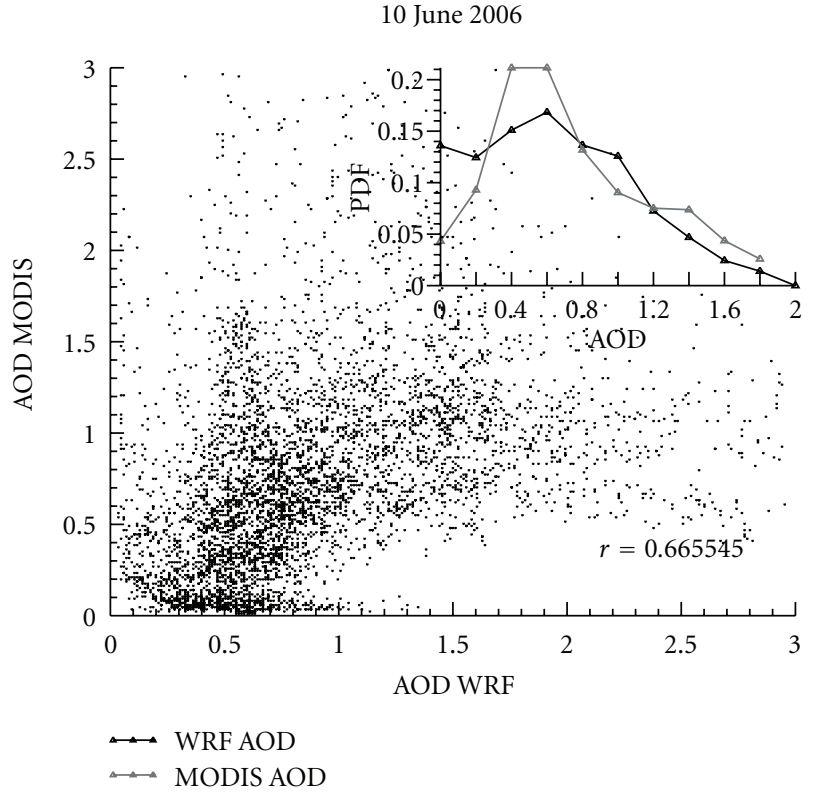

(b)

FIgURE 7: AOT scatter plots for 1200 UTC over model domain (a) the 9th of June and (b) the 10th of June. Main plots represent MODIS AOT versus Model AOT, and inner plots represent PDFs on the same datasets.
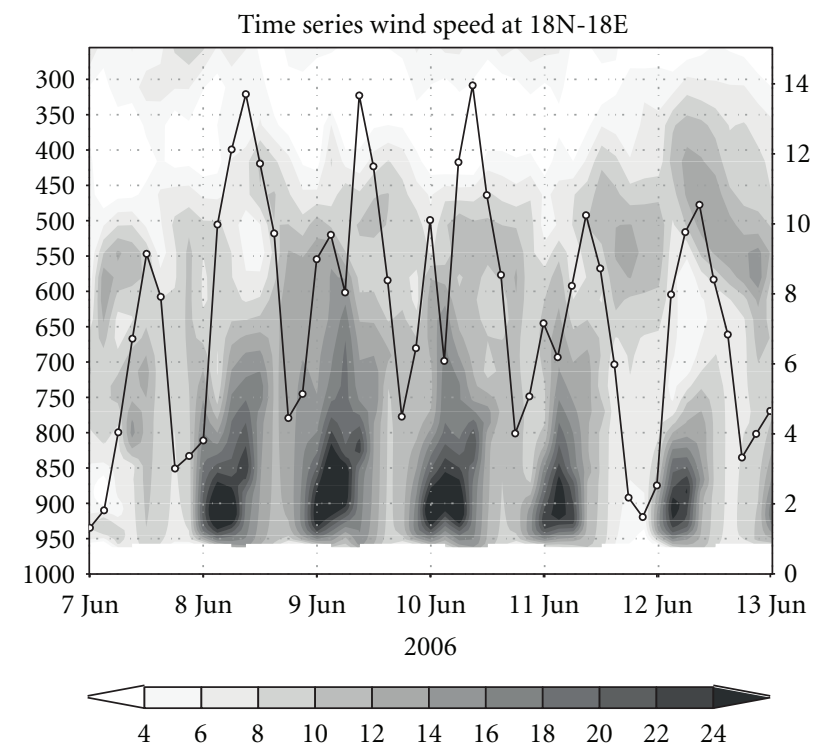

(a)

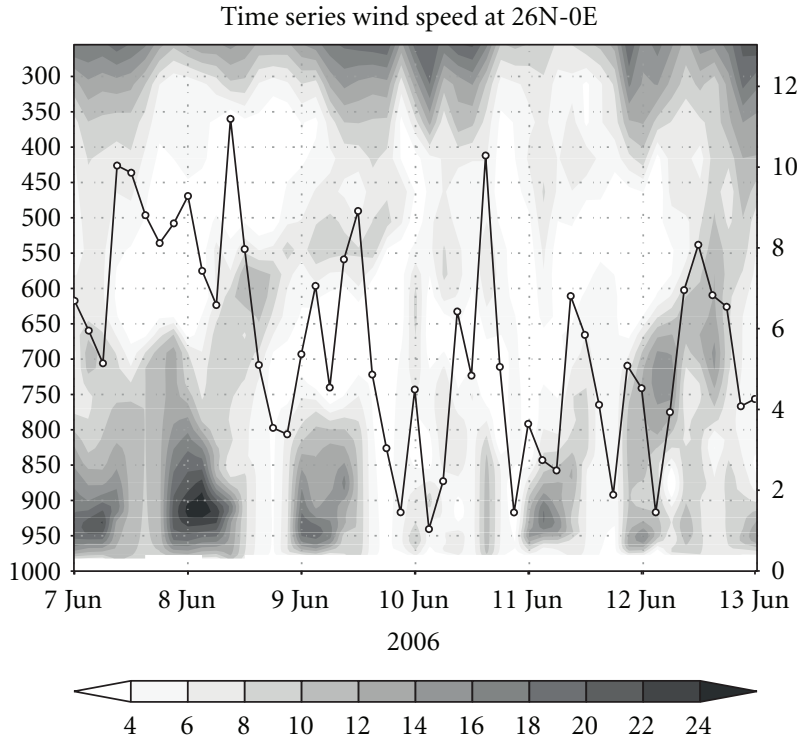

(b)

FIGURE 8: Time series of WRF-Chem EXP30-simulated wind speeds at the surface (10 $\mathrm{m}$ height, line) and in the lower atmosphere (shaded) over the (a) Bodélé Depression $\left(18^{\circ} \mathrm{N}, 18^{\circ} \mathrm{E}\right)$ and (b) central Algeria $\left(26^{\circ} \mathrm{N}, 0^{\circ} \mathrm{E}\right)$. These locations are roughly coincident with sources of dust features B1-B4 and A1-A2, respectively, in Figure 4.

moist airmass region, a feature also noted by Knippertz and Todd [31]. By the 12th of June the "V" plume has dispersed and dust transported south where peak AOT lies at $\sim 14^{\circ} \mathrm{N}$.

The WRF-Chem EXP30 at $30 \mathrm{~km}$ resolves reasonably well the inverted "V" plume. However, the eastern axis is rather weak because WRF-CHEM at this coarse resolution does not represent cold pools over Niger from DC3 and the associated haboobs. As such the simulated dust plume from Chad/Sudan (Section 3.3.1) in the Harmattan is effectively transported westward over Niger without pronounced modification by MCS outflow but rather is then advected northwards towards Algeria in the large scale southerly monsoon flow around the eastern flank of SSD2. Thus, the resulting EXP30 model simulation of the plume structure largely reflects emission 


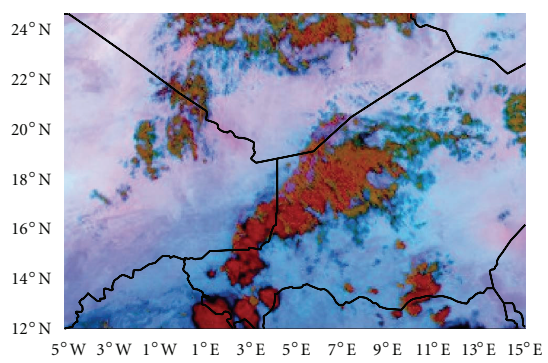

(a)

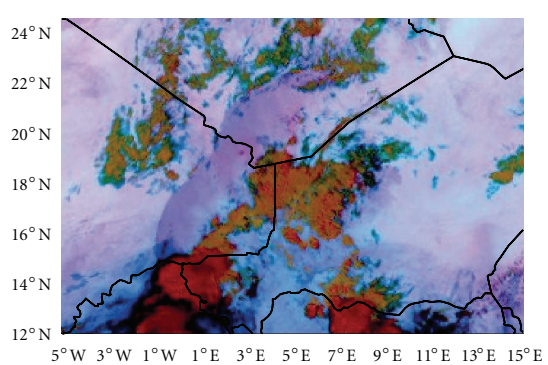

(d)

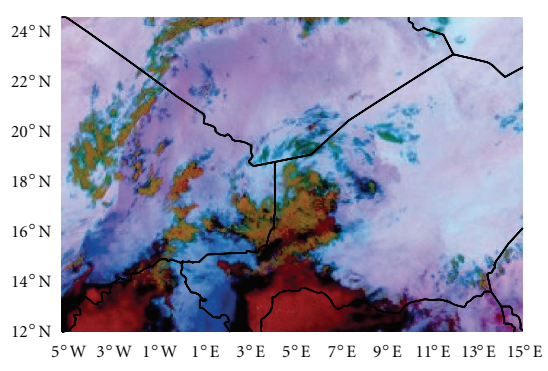

(g)

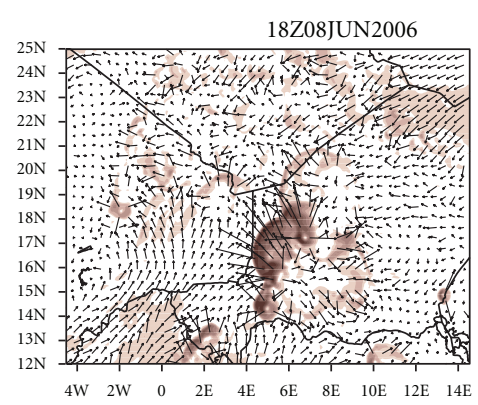

(b)

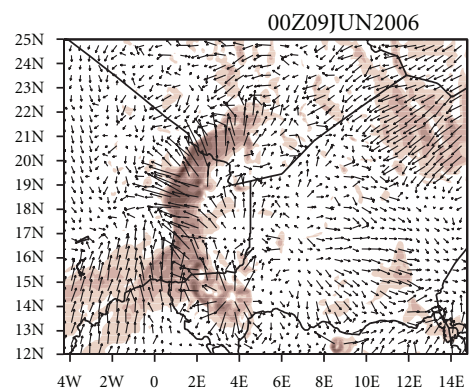

(e)

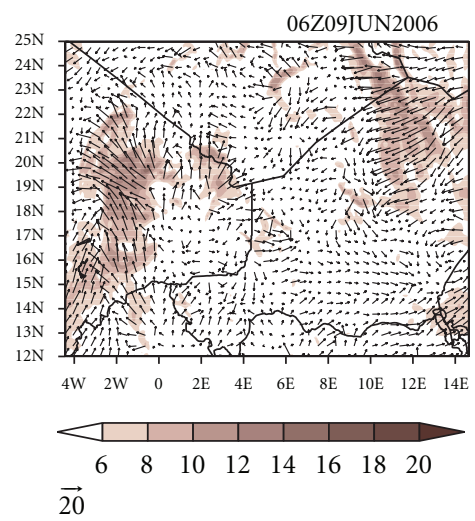

(h)

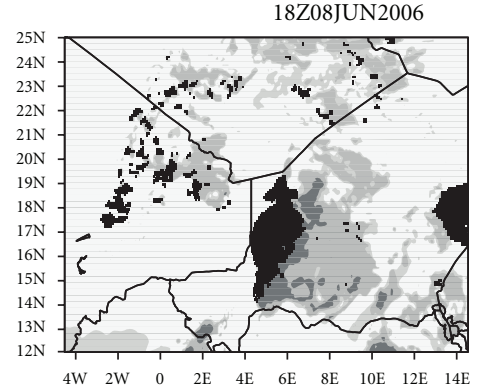

(c)

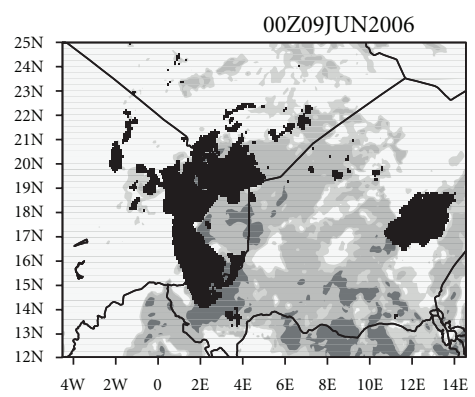

(f)

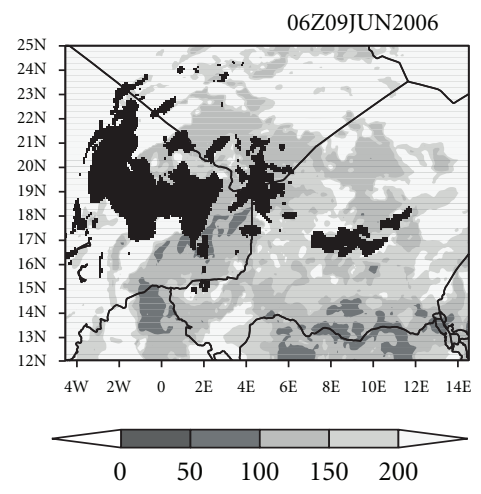

(i)

FIGURE 9: WRF-Chem EXP10 and Seviri dust product on the 8-9th of June. (a, b, and c) 18 UTC on the 9th of June, (d, e, and f) 00 UTC, (g, h, and i) 06 UTC. Left column: SEVIRI dust product. Center column: Wind speed (shaded) and direction (vectors) at $10 \mathrm{~m}$ height. Right column: Outgoing Longwave Radiation (shaded), and AOT $>0.5$ (black mask).

and transport within the largescale flow, culminating in the organisation of dust along the Harmattan/monsoon boundary around SSD2. However the model does not advect the dust far enough southwards over the monsoon flow, a feature highlighted in analysis of vertical dust structures in Section 3.3. The model produces a reasonable representation of large-scale dust emission and transport but without accurate representation of the mesoscale haboob phenomena that are substantially responsible. From an analysis of longterm satellite and reanalysis data Knippertz and Todd [31] suggest that the aerosol "hotpot" over the western Sahara in Mauritania-Mali-Algeria collocated with the SHL during summer is substantially a reflection of such emission and transport processes rather than local emission as previously inferred. As such, in this case WRF-CHEM EXP30 produces a broad scale dust plume with a realistic horizontal location but resulting from processes different from reality. The averaged surface dust emissions for the period from the 7th to the 12th of the June in the WRF-Chem model are equal to $200 \mathrm{~g} \mathrm{~m}^{-2} \mathrm{~d}^{-1}$.

\subsection{Vertical Structure of the Saharan Atmosphere and Dust} Distribution. The characteristics of the vertical dust profile are important in determining the nature of the direct and semidirect effect of dust on the atmosphere, which can then feed back onto dust emission and transport processes. The complex conditions of emission from various multiscale meteorological phenomena and subsequent horizontal and vertical transport over a number of days lead to interesting vertical structures of dust loading, closely coupled to the thermodynamical structure of the Saharan atmosphere. To 


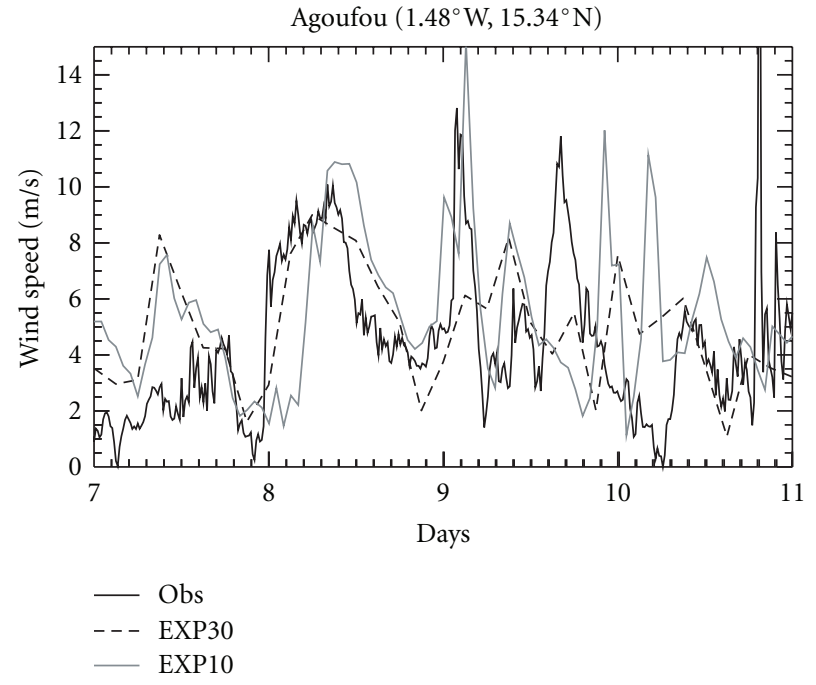

(a)

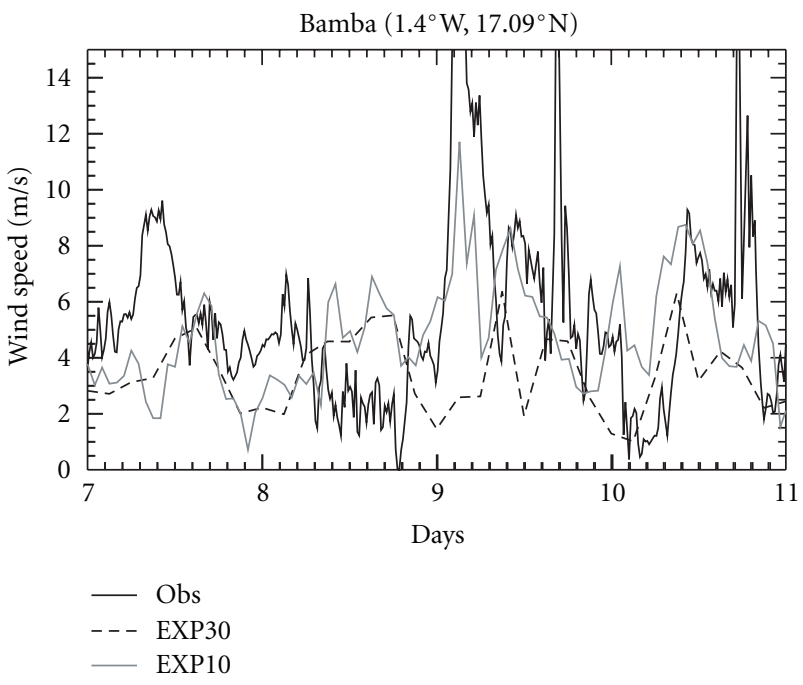

(b)

FIgURE 10: Time series of WRF-Chem-simulated and observed wind speed at $10 \mathrm{~m}$ height. Observations (black solid curve), EXP30 $30 \mathrm{~km}$ (grey solid curve) and EXP10 $10 \mathrm{~km}$ (grey dotted curve).

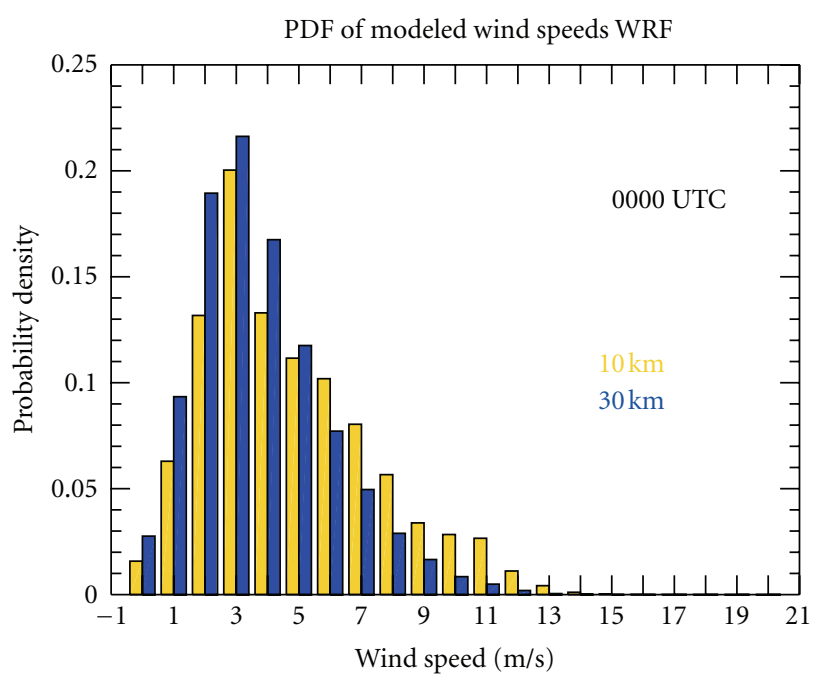

(a)

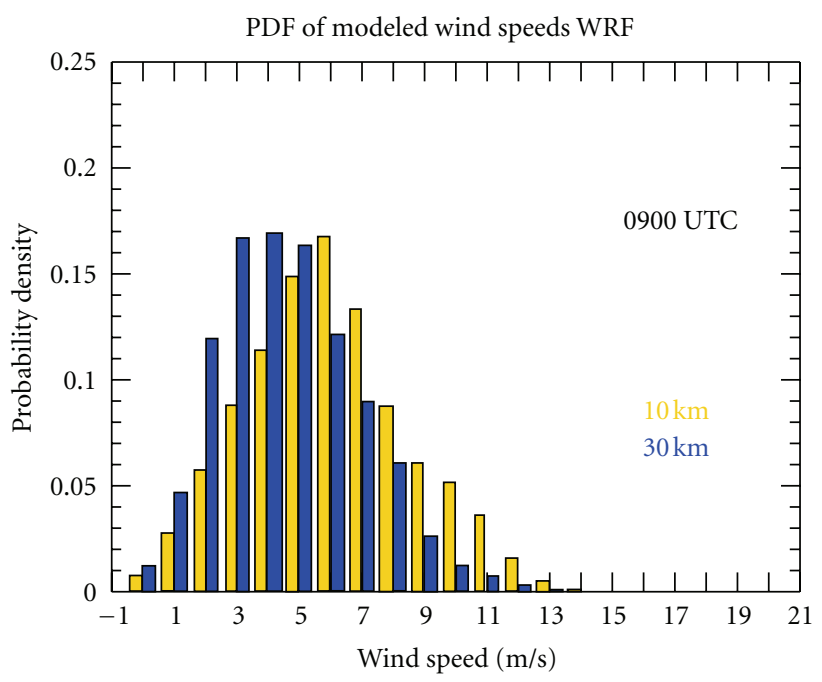

(b)

FIGURE 11: PDF for modeled wind speeds for EXP10 and EXP30 at (a) 00 UTC and (b) 0900 UTC.

analyse this we examine a full diurnal cycle and comparison with CALIOP extinction coefficient profiles.

Vertical profiles of dust, potential temperature, humidity, and horizontal winds from WRF-CHEM EXP30 along a latitude at $10^{\circ} \mathrm{E}$ for over one characteristic diurnal cycle on the 9th of June are examined (Figure 12). Lidar extinction coefficient observations from CALIOP orbits close to $10^{\circ} \mathrm{E}$ at 12.41 UTC on the 9th of June and 01.06 UTC on the 10th are shown for comparison (Figure 13). A number of key structures in the atmosphere can be identified. (i) The shallow moist and cool monsoon flow south of the ITD undercut the dry Saharan air to the north. The diurnal cycle in the monsoon flow is such that the ITD advances/retreats by $\sim 5^{\circ}$ latitude from about $12^{\circ} \mathrm{N}$ at $18.00 \mathrm{UTC}$ to about $17^{\circ} \mathrm{N}$ at 06.00 UTC (Figure 12). (ii) A well mixed, deep and dry convective boundary layer develops during the day up to height of about $6 \mathrm{~km}$ in the afternoon. This is the Saharan convective boundary layer (SCBL) and extends north from the ITD to $\sim 27^{\circ} \mathrm{N}$. (iii) At night, surface cooling decouples this layer resulting in an elevated residual Saharan convective boundary layer above the surface inversion. This residual layer then overrides the monsoon flow.

Dust emission and transport are strongly controlled by these features. During the early hours of the 9th of June a dust plume centred on $17^{\circ} \mathrm{N}$ resides throughout the vertical extent of the residual boundary layer from above the surface temperature inversion to about $5.5 \mathrm{~km}$ height (Figures 9(a)$9(\mathrm{~d})$ ). This is the plume from the Bodéle Depression 


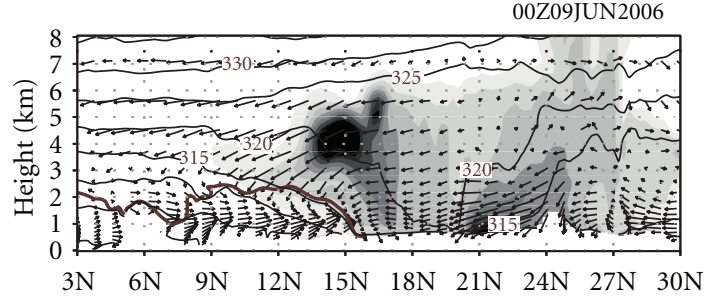

(a)

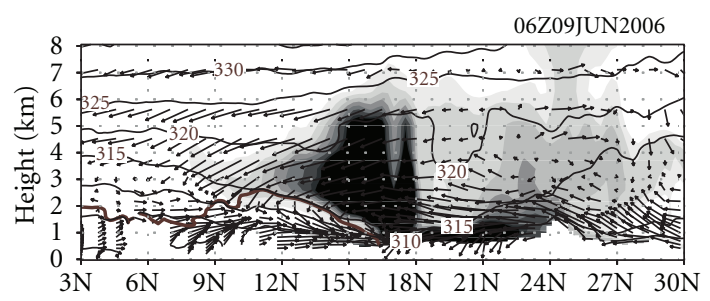

(c)

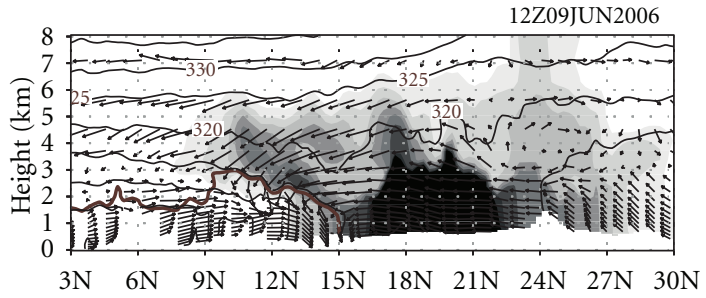

(e)

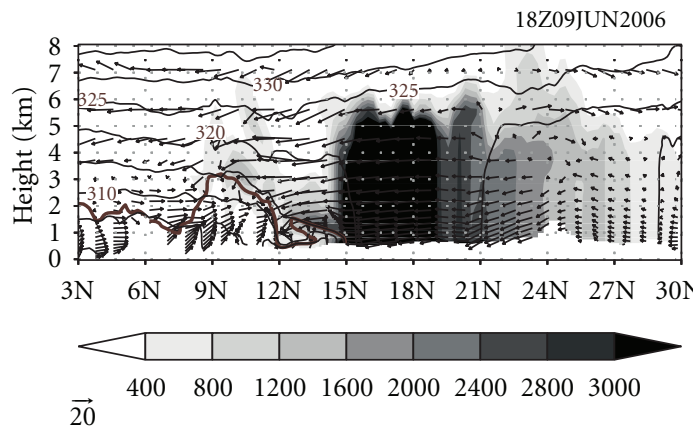

(g)

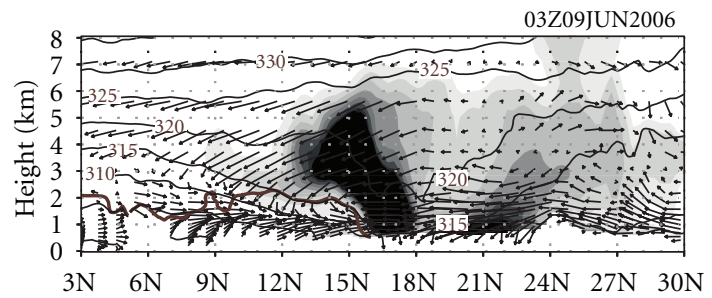

(b)

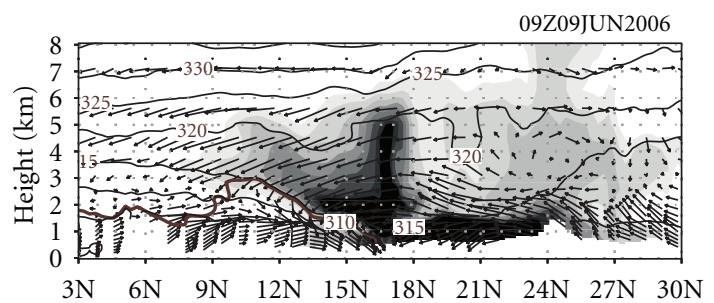

(d)

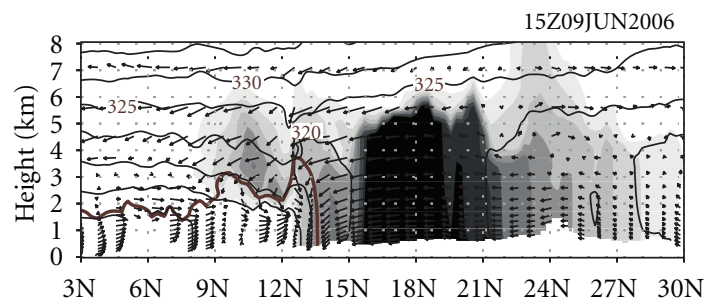

(f)

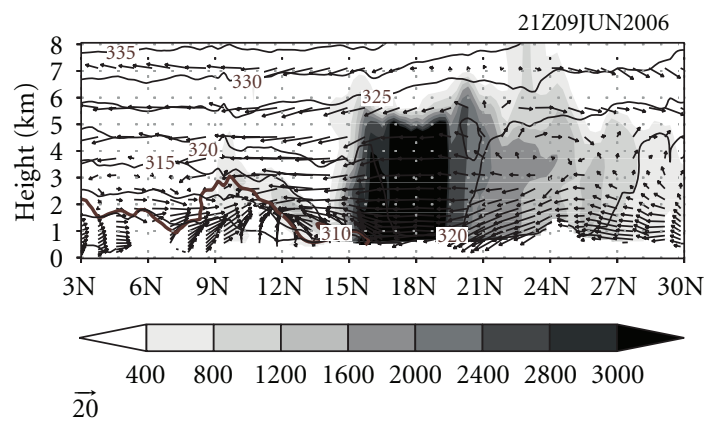

(h)

FIGURE 12: Vertical profiles of atmospheric structure and dust load from WRF-Chem EXP30 (30 km). Cross-section is at $10^{\circ} \mathrm{E}$. The figure shows the diurnal cycle on the 9th of June at (a) 0000 UTC, (b) 0300 UTC, (c) 0600 UTC, (d) 0900 UTC, (e) 1200 UTC, (f) 1500 UTC, and (g) 1800 UTC.

(B1 in Figure 4) emitted the previous day and advected east to $\sim 10^{\circ} \mathrm{E}$. The horizontal and vertical extent is verified from the CALIOP observations at 12.41 UTC on the 9th of June (Figure 13(a)).

During the morning local emission occurs at $16-21^{\circ} \mathrm{N}$ over Niger (Figures 9(d)-9(e)) as the nocturnal LLJ in the Harmattan flow is mixed to the surface, where $10 \mathrm{~m}$ winds exceed $12 \mathrm{~m} \mathrm{~s}^{-1}$ at 09.00 UTC. This emission is then rapidly mixed through the deep boundary layer to $\sim 6 \mathrm{~km}$ height by 18 UTC (Figures 10(f) and 10(g)) representing an effective diurnal "dust pump" into the SCBL. The following night (not shown) the near surface temperature inversion decouples the surface and atmosphere above creating another elevated dust layer in the residual SBL.

This dusty residual layer appears to be advected along slanting isentropes over the monsoon flow leading to an elevated wedge of high aerosol south to about $10^{\circ} \mathrm{N}$ by 12 UTC. This elevated southward dust transport is again confirmed by comparison with the CALIOP extinction coefficient profiles (Figures 13(a) and 13(b)). Overall, both WRF-CHEM and CALIOP broadly represent the characteristic features of a deep dusty SCBL to about $6 \mathrm{~km}$ height north of the ITD and southward advection of dust over the monsoon layer. We cannot expect the model to replicate all aspects of 

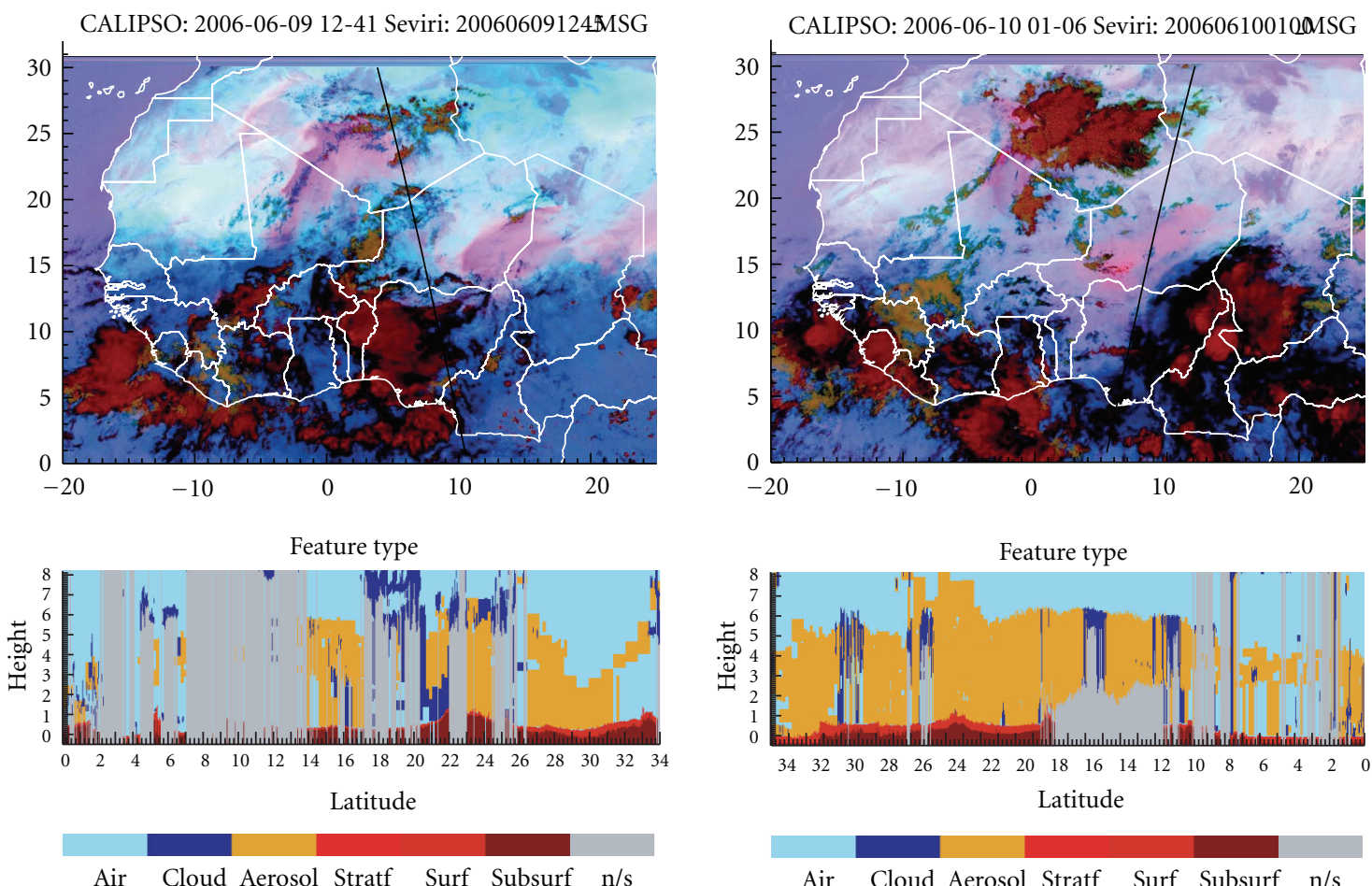

Air Cloud Aerosol Stratf Surf Subsurf n/s

CALIOP extinction_coefficient_532

Date: 2006-06-09 Time: 12-41
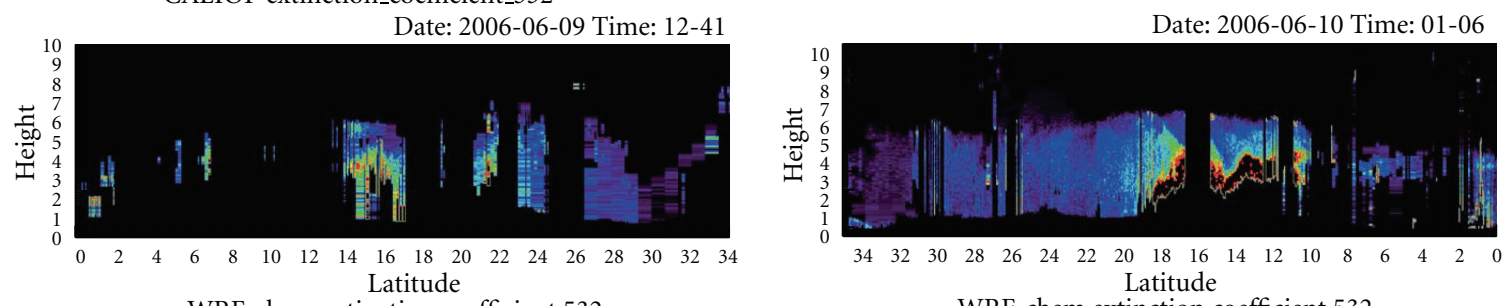

WRF-chem extinction coefficient 532
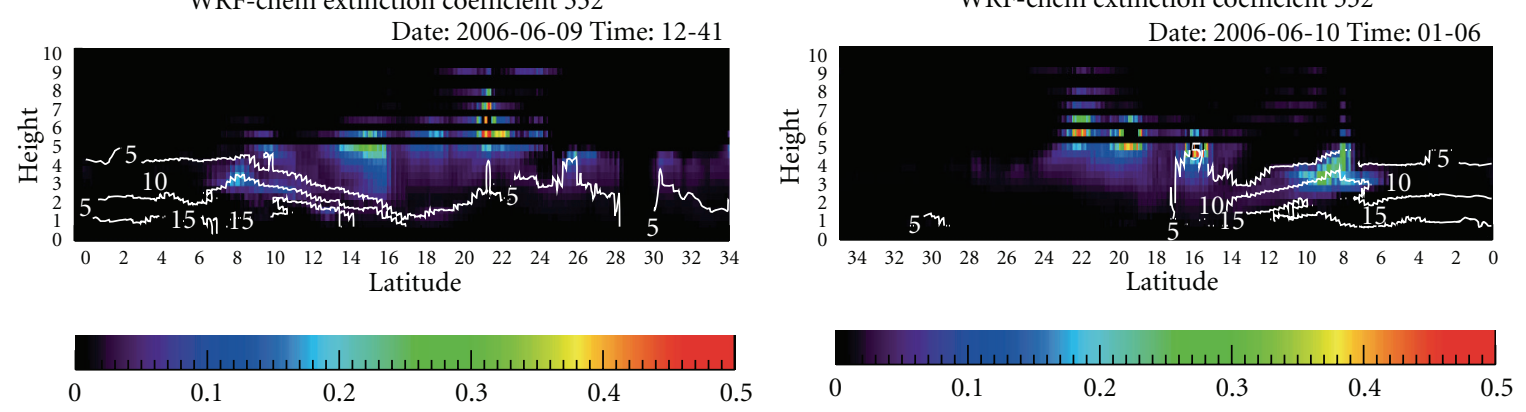

FIGURE 13: SEVIRI false color dust product imagery. Solid line indicates the CALIPSO track. (b) CALIOP L2 VFM product. (c) CALIOP L2 extinction coefficient (d) WRF-Chem extinction coefficient and water vapor mixing ratio g kg (contour). Left column: day-pass at 12: 41 UTC on the 9th of June, 2006. Right column: night-pass at $01: 06$ UTC on the 10th of June, 2006.

the detailed dust structure given errors in simulation of mesoscale dust emission events. Nevertheless, there are detailed differences that may point to further limitations in the model simulations. Notably, (i) the dust concentration in the upgliding over the monsoon flow may be too low relative to that in the SCBL (e.g., Figures 11(a) and 11(b)). Diagnosis of this is problematic but it may be a result of excessive deposition in the model. (ii) The height of the top of the dust layer appears rather more variable in the model than suggested by CALIOP. Preliminary comparison of vertical profiles of temperature and humidity between model and radiosonde at Niamey and Agadez indicates that the model does not replicate the strength of isothermal and inversion layers especially at $\sim 6 \mathrm{~km}$ height at the top of the Saharan 
convective layer (not shown). As a result entrainment of clear air from the free troposphere may be rather too strong resulting in a more variable dust profile.

\section{Summary}

The ability of the WRF-Chem model incorporating the GOCART dust scheme and the MOSAIC aerosol model to simulate processes of dust emissions and transport from over North Africa during summer was evaluated. The study focussed on the period from the 7th to 15th of June, 2006, during the AMMA Special Observing Period (SOP) in the West African Monsoon onset phase [57]. This period is particularly interesting for model evaluation as dust activity is pronounced and the associated processes of emission are manifold. Model simulations were confronted with a suite of satellite and surface observations. Evaluation implicate of synoptic and mesoscale atmosphere processes as drivers of dust plume events. Within the northeasterly Harmattan flow strong surface winds and dust outbreaks were caused by anomalies in the pressure gradient across north Africa associated with synoptic scale variability in both the midlatitudes and African easterly wave disturbances. Within the southwest monsoon circulation, monsoon surges around the AEW surface troughs facilitated moist convection well into the Saharan sector. These convective events often produce cold pool density currents driven by evaporation of precipitation in dry lower layers, which cause the haboob dust front events.

WRF-Chem running at $30 \mathrm{~km}$ over most of North Africa represents well these synoptic scale features and in most cases the associated dust emission from preferential dust sources in the Bodélé Depression, Libya, Sudan, and Algeria, many of which are associated with erodible material surface drainage systems. The 4-dimensional space-time evolution of emission, transport, and organisation of dust plumes broadly matches observations although there are errors in the fine details.

However, the haboob dust features are not at all well simulated at $30 \mathrm{~km}$ model resolution due to inadequacies in the convective parameterisation to simulate downdraughts. During the study period haboobs contributed a substantial proportion of total dust. The dust fronts can be of the order of $1000 \mathrm{~km}$ in length and propagate distances of many hundreds of $\mathrm{km}$. Limited analysis of WRF-CHEM at $10 \mathrm{~km}$ resolution indicated that the structure of cold pool flows associated the deep convection and the associated dust emission can be well simulated.

Following emission the dust plumes are transported and organised in the Saharan/monsoon circulation such that dust from many processes is mixed horizontally and vertically. The comparative analysis between observations from CALIOP and WRF-Chem simulations demonstrates the model efficacy to simulate the 3D structure of dust transport over the Sahara and Sahel.

Overall, the main features of the idealised summary of Saharan dust processes during summer of Cuesta et al. [9] are identifiable in this case and WRF-CHEM replicates these well. There is, therefore, a strong basis for accurate forecasting of dust events associated with synoptic scale events, when model dust emission parameterisation is suitably calibrated. Forecasting of the haboob events, an important driver of the dust cycle in summer, is more problematic. Further analysis of high-resolution model simulations is necessary to address this issue.

\section{References}

[1] N. C. Hsu, S. C. Tsay, M. D. King, and J. R. Herman, "Aerosol properties over bright-reflecting source regions," IEEE Transactions on Geoscience and Remote Sensing, vol. 42, no. 3, pp. 557-569, 2004.

[2] P. R. Buseck and M. Pósfai, "Airborne minerals and related aerosol particles: effects on climate and the environment," Proceedings of the National Academy of Sciences of the United States of America, vol. 96, no. 7, pp. 3372-3379, 1999.

[3] N. M. Mahowald, A. R. Baker, G. Bergametti et al., "Atmospheric global dust cycle and iron inputs to the ocean," Global Biogeochemical Cycles, vol. 19, no. 4, Article ID GB4025, 15 pages, 2005.

[4] P. Forster, V. Ramaswamy, P. Artaxo et al., "Changes in atmospheric constituents and in radiative forcing," in Climate Change 2007: The Physical Science Basis. Contribution of Working Group I to the Fourth Assessment Report of the Intergovernmental Panel on Climate Change, S. Solomon, D. Qin, and M. Manning, Eds., chapter 2, pp. 129-234, Cambridge University Press, New York, NY, USA, 2007.

[5] N. J. Middleton and A. S. Goudie, "Saharan dust: sources and trajectories," Transactions of the Institute of British Geographers, vol. 26, no. 2, pp. 165-181, 2001.

[6] R. Washington, M. C. Todd, S. Engelstaedter, S. Mbainayel, and F. Mitchell, "Dust and the low-level circulation over the Bodélé Depression, Chad: observations from BoDEx 2005," Journal of Geophysical Research D, vol. 111, no. 3, Article ID D03201, 15 pages, 2006.

[7] M. C. Todd, R. Washington, J. V. Martins et al., "Mineral dust emission from the Bodélé Depression nothern Chad, during BoDEx 2005," Journal of Geophysical Research D, vol. 112, no. 6, Article ID D06207, 12 pages, 2007.

[8] K. Schepanski, I. Tegen, B. Laurent, B. Heinold, and A. Macke, "A new Saharan dust source activation frequency map derived from MSG-SEVIRI IR-channels," Geophysical Research Letters, vol. 34, no. 18, Article ID L18803, 5 pages, 2007.

[9] J. Cuesta, J. H. Marsham, D. J. Parker, and C. Flamant, "Dynamical mechanisms controlling the vertical redistribution of dust and the thermodynamic structure of the West Saharan atmospheric boundary layer during summer," Atmospheric Science Letters, vol. 10, no. 1, pp. 34-42, 2009.

[10] J. M. Prospero, "African dust in America," Geotimes, vol. 46, no. 11, pp. 24-27, 2001.

[11] R. Washington, M. Todd, N. J. Middleton, and A. S. Goudie, "Dust-storm source areas determined by the total ozone monitoring spectrometer and surface observations," Annals of the Association of American Geographers, vol. 93, no. 2, pp. 297313, 2003.

[12] S. Engelstaedter and R. Washington, "Atmospheric controls on the annual cycle of North African dust," Journal of Geophysical Research D, vol. 112, no. 3, Article ID D03103, 14 pages, 2007.

[13] D. Hayward and J. S. Oguntoyinbo, Climatology of West Africa, Barnes and Neble Books, Totowa, NJ, USA, 1987. 
[14] A. E. Kalu, "The African dust plume: its characteristics and propagation across West Africa in Winter," in Saharan Dust, Mobilization, Transport, Deposition, C. Morales, Ed., pp. 95118, John Wiley \& Sons, New York, NY, USA, 1979.

[15] D. B. Karam, C. Flamant, J. Cuesta, J. Pelon, and E. Williams, "Dust emission and transport associated with a Saharan depression: February 2007 case," Journal of Geophysical Research D, vol. 115, no. 13, Article ID D00H27, 19 pages, 2010.

[16] P. Knippertz, C. Deutscher, K. Kandler, T. Müller, O. Schulz, and L. Schütz, "Dust mobilization due to density currents in the Atlas region: observations from the Saharan Mineral Dust Experiment 2006 field campaign," Journal of Geophysical Research D, vol. 112, no. 21, Article ID D21109, 14 pages, 2007.

[17] R. Washington and M. C. Todd, "Atmospheric controls on mineral dust emission from the Bodélé Depression, Chad: the role of the low level jet," Geophysical Research Letters, vol. 32, no. 17, Article ID L17701, 5 pages, 2005.

[18] B. J. H. van de Wiel, A. F. Moene, G. J. Steeneveld, P. Baas, F. C. Bosveld, and A. A. M. Holtslag, "A conceptual view on inertial oscillations and nocturnal low-level jets," Journal of the Atmospheric Sciences, vol. 67, no. 8, pp. 2679-2689, 2010.

[19] M. C. Todd, R. Washington, S. Raghavan, G. Lizcano, and P. Knippertz, "Regional model simulations of the Bodélé lowlevel jet of Northern Chad during the Bodélé dust experiment (BoDEx 2005)," Journal of Climate, vol. 21, no. 5, pp. 9951012, 2008.

[20] N. M. J. Hall and P. Peyrille, "Dynamics of the West African monsoon," Journal de Physique IV, vol. 139, pp. 81-99, 2006.

[21] C. D. Thorncroft and M. Blackburn, "Maintenance of the African easterly jet," Quarterly Journal of the Royal Meteorological Society, vol. 125, no. 555, pp. 763-786, 1999.

[22] C. Lavaysse, C. Flamant, S. Janicot et al., "Seasonal evolution of the West African heat low: a climatological perspective," Climate Dynamics, vol. 33, no. 2-3, pp. 313-330, 2009.

[23] D. J. Parker, R. R. Burton, A. Diongue-Niang et al., "The diurnal cycle of the West African monsoon circulation," Quarterly Journal of the Royal Meteorological Society, vol. 131, no. 611, pp. 2839-2860, 2005.

[24] C. Lavaysse, C. Flamant, S. Janicot, and P. Knippertz, "Links between African easterly waves, midlatitude circulation and intraseasonal pulsations of the West African heat low," Quarterly Journal of the Royal Meteorological Society, vol. 136, no. 1, pp. 141-158, 2010.

[25] K. H. Cook, "Generation of the African easterly jet and its role in determining West African precipitation," Journal of Climate, vol. 12, no. 5, pp. 1165-1184, 1999.

[26] R. W. Burpee, "Comparison of the structure of easterly wave disturbances in Western Africa, the Eastern Atlantic, and the Caribbean during gate," Bulletin of the American Meteorological Society, vol. 59, no. 11, article 1534, 1978.

[27] A. H. Fink and A. Reiner, "Spatiotemporal variability of the relation between African Easterly Waves and West African Squall Lines in 1998 and 1999," Journal of Geophysical Research D, vol. 108, no. 11, Article ID 4332, 17 pages, 2003.

[28] A. Diongue, J. P. Lafore, J. L. Redelsperger, and R. Roca, "Numerical study of a Sahelian synoptic weather system: initiation and mature stages of convection and its interactions with the large-scale dynamics," Quarterly Journal of the Royal Meteorological Society, vol. 128, no. 584, pp. 1899-1928, 2002.

[29] K. Schepanski and P. Knippertz, "Soudano-Saharan depressions and their importance for precipitation and dust: a new perspective on a classical synoptic concept," Quarterly Journal of the Royal Meteorological Society, vol. 137, no. 659, pp. 14311445, 2011.
[30] C. Flamant, J. P. Chaboureau, D. J. Parker et al., "Airborne observations of the impact of a convective system on the planetary boundary layer thermodynamics and aerosol distribution in the inter-tropical discontinuity region of the West African Monsoon," Quarterly Journal of the Royal Meteorological Society, vol. 133, no. 626, pp. 1175-1189, 2007.

[31] P. Knippertz and M. C. Todd, "The central west Saharan dust hot spot and its relation to African easterly waves and extratropical disturbances," Journal of Geophysical Research D, vol. 115, no. 12, Article ID D12117, 14 pages, 2010.

[32] C. Flamant, P. Knippertz, D. J. Parker et al., "The impact of a mesoscale convective system cold pool on the northward propagation of the intertropical discontinuity over West Africa," Quarterly Journal of the Royal Meteorological Society, vol. 135, no. 638, pp. 139-159, 2009.

[33] D. Bou Karam, C. Flamant, P. Knippertz et al., "Dust emissions over the Sahel associated with the West African monsoon intertropical discontinuity region: a representative casestudy," Quarterly Journal of the Royal Meteorological Society, vol. 134, no. 632, pp. 621-634, 2008.

[34] K. R. Knupp and W. R. Cotton, "Convective cloud downdraft structure: an interpretive survey," Reviews of Geophysics, vol. 23, no. 2, pp. 183-215, 1985.

[35] B. Sultan and S. Janicot, "Abrupt shift of the ITCZ over West Africa and intra-seasonal variability," Geophysical Research Letters, vol. 27, no. 20, pp. 3353-3356, 2000.

[36] L. J. Sutton, "Haboobs," Quarterly Journal of the Royal Meteorological Society, vol. 57, pp. 143-161, 1931.

[37] J. S. Farquharson, "Haboobs and instability in the Sudan," Quarterly Journal of the Royal Meteorological Society, vol. 63, no. 274, pp. 393-414, 1937.

[38] C. Jones, N. Mahowald, and C. Luo, "Observational evidence of African desert dust intensification of easterly waves," Geophysical Research Letters, vol. 31, no. 17, Article ID L17208, 4 pages, 2004.

[39] E. Williams, N. Nathou, E. Hicks et al., "The electrification of dust-lofting gust fronts ("haboobs") in the Sahel," Atmospheric Research, vol. 91, no. 2-4, pp. 292-298, 2009.

[40] S. D. Miller, A. P. Kuciauskas, M. Liu et al., "Haboob dust storms of the southern Arabian Peninsula," Journal of Geophysical Research D, vol. 113, no. 1, Article ID D01202, 26 pages, 2008.

[41] P. Knippertz, "Dust emissions in the West African heat trough-the role of the diurnal cycle and of extratropical disturbances," Meteorologische Zeitschrift, vol. 17, no. 5, pp. 553$563,2008$.

[42] M. Gamo, "Thickness of the dry convection and large-scale subsidence above deserts," Boundary-Layer Meteorology, vol. 79, no. 3, pp. 265-278, 1996.

[43] V. M. Karyampudi and T. N. Carlson, "Analysis and numerical simulations of the Saharan air layer and its effect on easterly wave disturbances," Journal of the Atmospheric Sciences, vol. 45, no. 21, pp. 3102-3136, 1988.

[44] J. Michalakes, D. Duhia, D. Gill, T. Henderson, J. Klemp, and W. Wang, "The weather research and forecast model: software architecture and performance," in Proceedings of the 11th ECMWF Workshop on the Use of High Performance Computing in Meteorology, W. Zwieflhofer and G. Mozdzynski, Eds., pp. 156-168, World Scientific, 2005.

[45] G. A. Grell, S. E. Peckham, R. Schmitz et al., "Fully coupled "online" chemistry within the WRF model," Atmospheric Environment, vol. 39, no. 37, pp. 6957-6975, 2005. 
[46] P. Ginoux, M. Chin, I. Tegen et al., "Sources and distributions of dust aerosols simulated with the GOCART model," Journal of Geophysical Research D, vol. 106, no. 17, pp. 20255-20273, 2001.

[47] M. Chin, P. Ginoux, S. Kinne et al., "Tropospheric aerosol optical thickness from the GOCART model and comparisons with satellite and sun photometer measurements," Journal of the Atmospheric Sciences, vol. 59, no. 3, pp. 461-483, 2002.

[48] I. Tegen and I. Fung, "Modeling of mineral dust in the atmosphere: sources, transport, and optical thickness," Journal of Geophysical Research, vol. 99, no. 11, pp. 22897-22914, 1994.

[49] R. S. Defries and J. R. G. Townshend, "NDVI-derived land cover classifications at a global scale," International Journal of Remote Sensing, vol. 15, no. 17, pp. 3567-3586, 1994.

[50] C. Zhao, X. Liu, L. R. Leung et al., "The spatial distribution of mineral dust and its shortwave radiative forcing over North Africa: modeling sensitivities to dust emissions and aerosol size treatments," Atmospheric Chemistry and Physics, vol. 10, no. 18, pp. 8821-8838, 2010.

[51] Y. Wang, C. N. Long, L. R. Leung et al., "Evaluating regional cloud-permitting simulations of the WRF model for the Tropical Warm Pool International Cloud Experiment (TWPICE), Darwin, 2006," Journal of Geophysical Research D, vol. 114, no. 21, Article ID D21203, 21 pages, 2009.

[52] B. Pohl, J. Crétat, and P. Camberlin, "Testing WRF capability in simulating the atmospheric water cycle over Equatorial East Africa," Climate Dynamics, vol. 37, no. 7-8, pp. 1357-1379, 2011.

[53] E. Flaounas, S. Bastin, and S. Janicot, "Regional climate modelling of the 2006 West African monsoon: sensitivity to convection and planetary boundary layer parameterisation using WRF," Climate Dynamics, vol. 36, no. 5-6, pp. 10831105, 2011.

[54] G. A. Grell and D. Dévényi, “A generalized approach to parameterizing convection combining ensemble and data assimilation techniques," Geophysical Research Letters, vol. 29, no. 14, Article ID 1693, 4 pages, 2002.

[55] E. K. Gilliland and C. M. Rowe, "A comparison of cumulus parameterization schemes in the WRF model," in Proceedings of the 87th AMS Annual Meeting, San Antonio, Tex, USA, January 2007.

[56] T. Lebel, B. Cappelaere, S. Galle et al., "AMMA-CATCH studies in the Sahelian region of West-Africa: an overview," Journal of Hydrology, vol. 375, no. 1-2, pp. 3-13, 2009.

[57] J. L. Redelsperger, C. D. Thorncroft, A. Diedhiou, T. Lebel, D. J. Parker, and J. Polcher, "African Monsoon Multidisciplinary Analysis: an international research project and field campaign," Bulletin of the American Meteorological Society, vol. 87, no. 12, pp. 1739-1746, 2006.

[58] M. Legrand, A. Plana-Fattori, and C. N’Doumé, "Satellite detection of dust using the IR imagery of Meteosat 1. Infrared difference dust index," Journal of Geophysical Research D, vol. 106, no. 16, pp. 18251-18274, 2001.

[59] M. Vaughan, S. Young, D. Winker et al., "Fully automated analysis of space-based lidar data: an overview of the CALIPSO retrieval algorithms and data products," in Laser Radar Techniques for Atmospheric Sensing, vol. 5575 of Proceedings of SPIE, pp. 16-30, Maspalomas, Spain, September 2004.

[60] D. M. Winker, W. H. Hunt, and M. J. McGill, "Initial performance assessment of CALIOP," Geophysical Research Letters, vol. 34, no. 19, Article ID L19803, 5 pages, 2007.

[61] S.-H. Chen and W.-Y. Sun, "A one-dimensional time dependent cloud model," Journal of the Meteorological Society of Japan, vol. 80, no. 1, pp. 99-118, 2002.
[62] Z. I. Janjić, "Nonsingular implementation of the mellor-yamada level 2.5 scheme in the NCEP meso model," NCEP Office Note No. 437, 2002.

[63] L. Zobler, "A world soil file for global climate modelling," NASA Technical Memorandum 87802, 1986.

[64] C. Flamant, C. Lavaysse, M. C. Todd, J. P. Chaboureau, and J. Pelon, "Multl-platform observations of a springtime case of Bodélé and Sudan dust emission, transport and scavenging over West Africa," Quarterly Journal of the Royal Meteorological Society, vol. 135, no. 639, pp. 413-430, 2009.

[65] G. N. Kiladis, C. D. Thorncroft, and N. M. J. Hall, "Threedimensional structure and dynamics of African easterly waves. Part I: observations," Journal of the Atmospheric Sciences, vol. 63, no. 9, pp. 2212-2230, 2006.

[66] J. M. Prospero, P. Ginoux, O. Torres, S. E. Nicholson, and T. E. Gill, "Environmental characterization of global sources of atmospheric soil dust identified with the Nimbus 7 Total Ozone Mapping Spectrometer (TOMS) absorbing aerosol product," Reviews of Geophysics, vol. 40, no. 1, pp. 1-31, 2002.

[67] P. Knippertz, J. Trentmann, and A. Seifert, "High-resolution simulations of convective cold pools over the northwestern Sahara," Journal of Geophysical Research D, vol. 114, no. 8, Article ID D08110, 16 pages, 2009. 

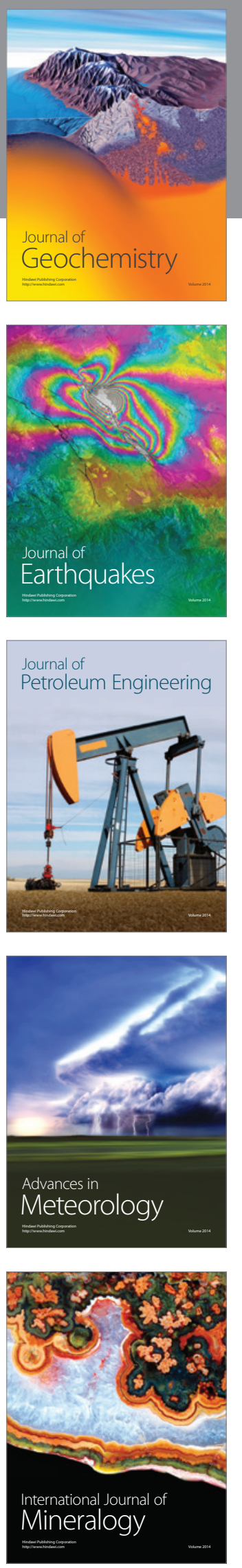
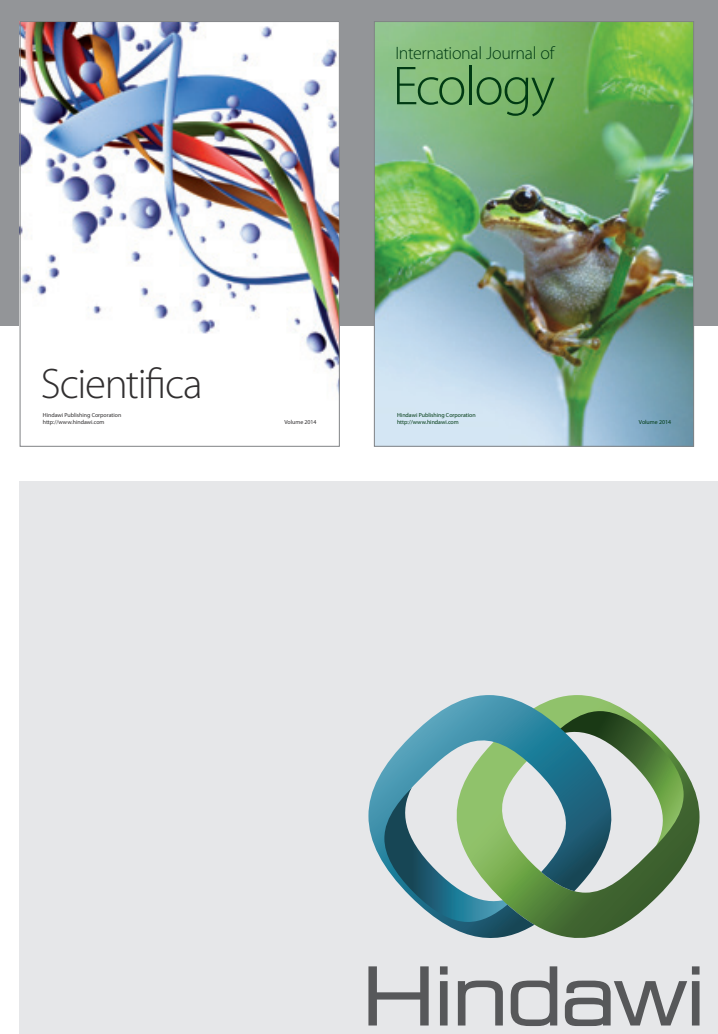

Submit your manuscripts at http://www.hindawi.com
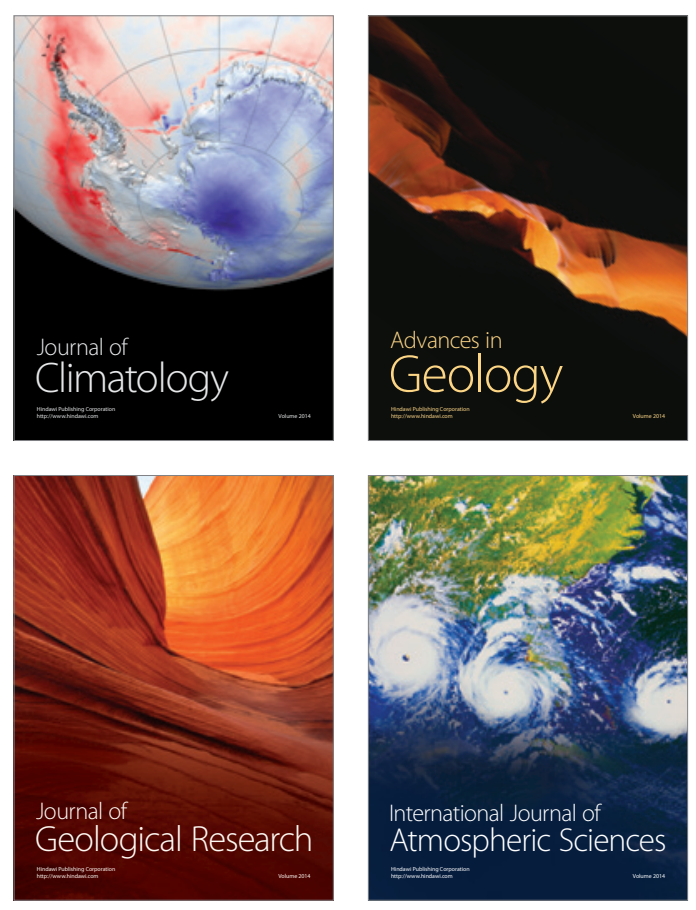
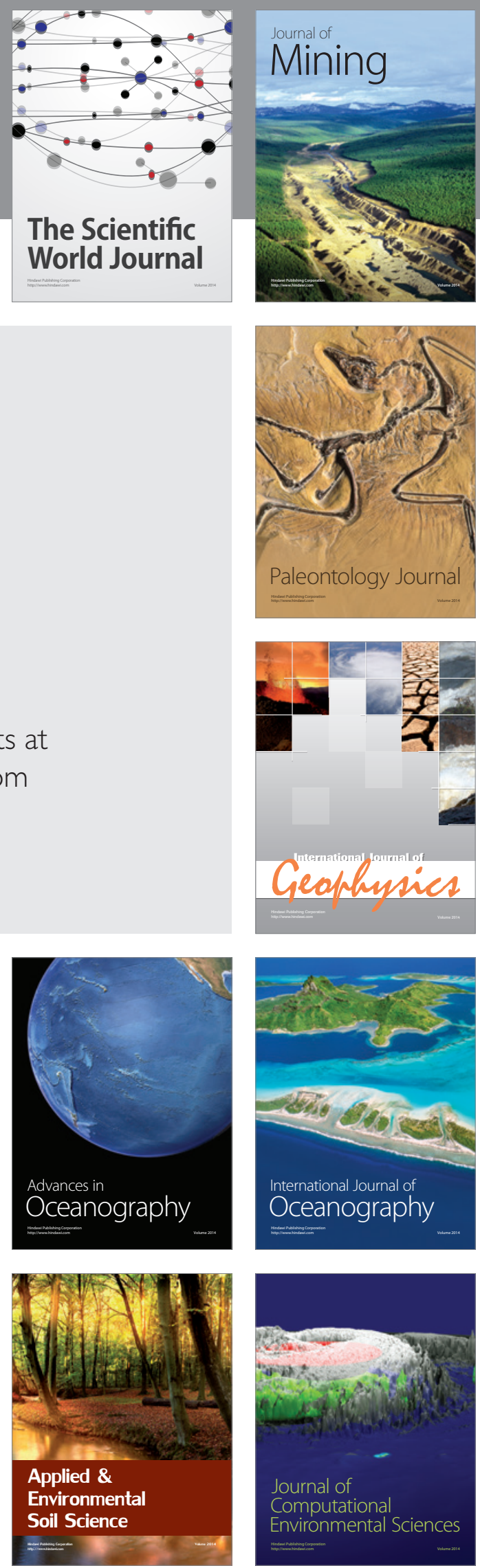